\title{
Tuzak nöropatilerde manyetik rezonans görüntüleme
}

\author{
Magnetic resonance imaging of entrapment neuropathies
}

\author{
Mehmet Yörübulut
}

Acıbadem Hastanesi, Ankara

\begin{abstract}
Tuzak nöropatiler, periferik sinirlerin anatomik gidiş yolları boyunca sıklıkla mekanik olarak basıya maruz kalmaları sonucunda, daha nadir olarak sinire direkt bası olmadan hareketler esnasında dinamik şekilde oluşur. Tanı için radyolojik görüntüleme yöntemlerinden manyetik rezonans (MR) görüntüleme sık olarak kullanılır. MR görüntüleme (konvansiyonel $M R$ ve $M R$ nörografi), basıya uğrayan sinirin morfolojisinde ortaya çıkan değişiklikleri ayrıntılı olarak gösterebildiği gibi, bu yöntemle basıyı oluşturan etmen ortaya konulur; ayrıca, çevre yumuşak ve kemik dokular hakkında da yeterli düzeyde bilgi verir.
\end{abstract}

Anahtar sözcükler: tuzaklanma; MR nörografi; sinyal artışı
Entrapment neuropathies, often as a result of exposure to mechanical compression of the peripheral nerve paths along the anatomic course, more rarely occurs dynamically during movement without direct nerve compression. Magnetic resonance (MR) imaging for the diagnosis is commonly used. With MR imaging (conventional MR and MR neurography), changes in the morphology of the nerve according to compression can be shown in detail. With this method, we can identify the factors that cause the entrapment, and at the same time we can have more satisfactory information about the bone and soft tissues nearby.

Key words: entrapment; MR neurography; hyperintensity
T uzak nöropatiler, periferik sinirlerin anatomik gidiş yolları boyunca, çoğunlukla fibrözfibroosseöz tünelleri geçişleri esnasında mekanik olarak basıya maruz kalmaları sonucunda oluşan nöropatilerdir. Daha nadir olarak, bu tür nöropatiler, sinire direkt bası olmadan, hareketler esnasında dinamik şekilde de oluşabilir. Klinik tablo, basıya uğrayan sinire bağlı olarak ortaya çıkar ve tuzak nöropatiler, vücudun herhangi bir anatomik bölgesinde görülebilir. ${ }^{[1]}$

\section{RADYOLOJIK TANI}

Tuzak nöropatilerde, tanı için radyolojik görüntüleme yöntemleri, manyetik rezonans (MR) görüntüleme, ultrasonografi, röntgen ve bigisayarlı tomografi incelemeleridir. Son iki yöntem radyasyon içerirken, daha çok basıya neden olan osseöz-kalsifiye yapıların görüntülemesinde ve nadiren ayırıcı tanı için kullanılır.
MR görüntüleme (konvansiyonel MR ve MR nörografi), basıya uğrayan sinirin morfolojisinde ortaya çıkan değişiklikleri ayrıntılı olarak gösterebildiği gibi, bu yöntemle basıyı oluşturan etmen ortaya konulur; ayrıca, çevre yumuşak ve kemik dokular hakkında da yeterli düzeyde bilgi verir. MR görüntüleme ile, sinirin innerve ettiği kasta denervasyon sonucunda oluşan akut ve kronik değişiklikler de izlenir. Akut fazda, kas ödemi, denervasyondan yaklaşık 24-48 saat sonra ortaya çıkar. Kasta yağlı atrofi ise, kronik denervasyon bulgusudur ve denervasyondan birkaç ay sonra ortaya çıkmaktadır. ${ }^{[2-3]}$

MR görüntüleme, invaziv olmayan bir inceleme tekniği olup, radyasyon içermez. Uzaysal çözünürlüğü yüksek olup, multiplanar görüntüleme yapılabilir. Tanı ve ayırıcı tanının yanı sıra, tedavinin medikal, girişimsel (enjeksiyon-blok) veya cerrahi olmasını büyük oranda etkiler. Ayrıca, cerrahi tedavi sonrasında oluşabilecek

- Illetişim adresi: Dr. Mehmet Yörübulut, Acıbadem Hastanesi 630. sok. No:6, Oran-Çankaya, 06450, Ankara Tel: 0312 - 5934467 e-posta: myorubulut@gmail.com

- Geliș tarihi: 13 Ekim 2015 Kabul tarihi: 13 Ekim 2015 
komplikasyonları değerlendirmede, diğer görüntüleme tekniklerine göre daha üstündür. İncelemede sıklıkla, normal anatomi, sagittal ve transvers planlarda alınacak T1 ağırlıklı (T1A) görüntülerle değerlendirilir. Sagittal, transvers ve koronal planlarda alınacak STIR (short tau inversion recovery) ve T2 ağırlıklı yağ baskılı sekanslarda, patoloji görüntülenir ve karakterize edilir. Kitle ve inflamasyonu belirlemek için, intravenöz yolla verilecek gadolinyum içeren kontrast maddeler sonrasında, üç düzlemde alınacak T1 ağırlıklı yağ baskıı sekanslara ihtiyaç duyulur. Ayrıca, MR nörografi incelemesi ile, etkilenen sinirin durumunu ayrıntılı olarak gösterilebilir. ${ }^{[3]}$ MR nörografi, uzun eko zamanına sahip olan ve çevrede bulunan damar ile sinir dışı diğer dokuları özel yöntemlerle baskılayarak sinirleri görüntüleyen bir yöntemdir. MR incelemede, etkilenen sinirin morfolojisi, kalınlığı, intensite değişikliği, lokalizasyonu ve devamlılığı hakkında bilgi edilinir. İncelemeler; 1,5 Tesla ve üzeri MR cihazlarında yapılmalı, incelenecek bölgelere uygun sargılar kullanılmalı, kesit kalınlığı $3 \mathrm{~mm}$ ve altında olmalıdır. Anatomik bölgenin özelliğine göre, kulanıcı hekim, incelemenin diğer özel parametrelerini literatüre uygun olarak ayarlamalıdır.

\section{Direkt Bulgular}

\section{Sinirin Intensitesi}

Normal sinir, T1A sekanslarda orta intensitede iken, T2A sekanslarında kasa göre hafif hiperintens izlenir. STIR veya MR nörografide ise, belirgin hiperintens sinyal özelliğindedir. Sinir patolojilerinde, bu intensitelerde farklıklık izlenir. Normal sinirlerde, iV gadolinyum enjeksiyonu sonrasında minimal kontrastlanma izlenirken, inflamasyon ve tümör olgularında bu kontrastlanma düzeyi artar.

\section{Sinirin Kalınlık ve Morfolojisi}

Her sinirin kalınlığı ve morfolojisi farklı olup, patolojilerin değişik evrelerinde değişkenlik gösterir. Basının akut döneminde, etkilenen sinirde sıklıkla ödem-inflamasyon ile uyumlu hiperintensite ve kalınlaşma izlenir. Süreç uzadıkça (kronik evrede), sinirde kalibrasyon kaybı gelişir ve hiperintensite azalır. Travmalarda ise, sinirlerde şişme, kalibrasyon kaybı ve tam kesi olabilir.

\section{İndirekt Bulgular}

Bu bulgular, etkilenen sinirin innerve ettiği kaslarda denervasyona bağlı gelişen değişikliklerdir. Akut dönemde (günler-haftalar) kasta, STIR sekanslarda diffüz-homojen hiperintensite izlenirken, T1A sekanslar normaldir. Kas morfolojisi normal izlenirken, faysa ve çevre yağ dokuda da anormal bulgu yoktur. Yırtık, rüptür, kanama, enfarkt ve enfeksiyonda, T1A ve STIR sekanslarda oluşan değişiklikler oldukça farklıdır.
Denervasyon süreci uzadıkça (aylar-kronik evre), kasta T1A sekanslarda hiperintensite gelişirken, volüm azalır (atrofi). STIR sekansındaki hiperintensite düzeyi bir miktar azalır. Bu bulgular, ileri evre hastalığa işaret eder ve kaslardaki hasar geri dönüşümsüzdür. ${ }^{[4]}$

\section{ALT EKSTREMITE TUZAK NÖROPATILERI}

Pelvis ve kalça bölgelerinde en çok etkilenen sinirler lumbosakral pleksus, femoral sinir, lateral kutanöz sinir, obturator sinir, siyatik sinir (piriformis sendromu) ve gluteal sinirdir. Alt ekstremitede en sık bası altında kalan sinirler ise, ana peroneal sinir ve dalları, tibial sinir ve dalları ile sural sinirdir. Lateral kutanöz sinir, femoral sinir, safenöz sinir, obturator sinir ve interdijital sinirler de basılanabilir. ${ }^{[1]}$

\section{Lumbosakral Pleksopati}

Lombusakral pleksus, L1-S3 sinir köklerinden oluşur ve psoas kasının posteriorundan başlar. Sonrasında, psoas kası bu yapıyı lateral (iliohipogastril, ilioinguinal, genitofemoral, femoral ve lateral kutanöz) ve mediyal (obturator sinir ve lumbosakral trunkus) olarak ikiye ayırır (Şekil 1).

Piriformis kası, siyatik sinirin anteriorunda yer alır ve bu kasın patolojilerinde (hipertrofi gibi) siyatik sinir

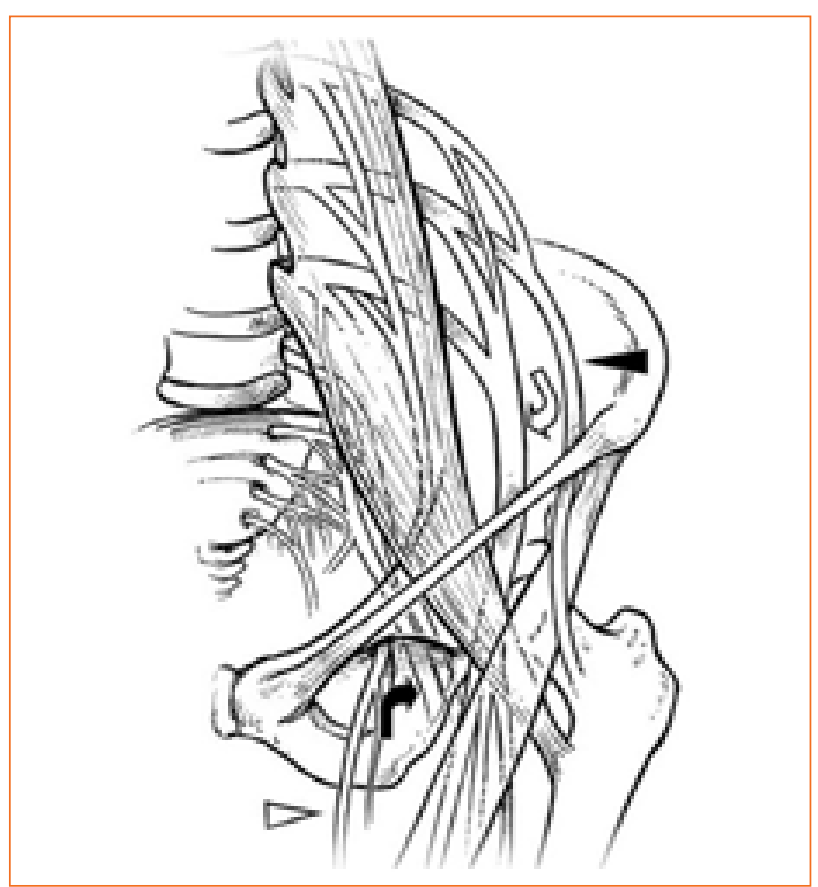

Şekil 1. Lumbosakral pleksus. Femoral sinir (açık ok) ve obturator sinir (açık ok başı), L2-L4 sinir köklerinden oluşur. Lateral kutanöz sinir (dolu ok başı), L2 ve L3 sinir köklerinden oluşurken, siyatik sinir (dolu ok) L4-S3 sinir köklerinden köken alır. 
sıklıkla etkilenir. Lumbosakral pleksus görüntülemede, T1A transvers ve koronal, T2A-STIR transvers, koronal ve sagittal görüntülerle birlikte alınacak MR nörografi, patolojiyi sıklıkla ortaya koyar. Gerekli durumlarda, oblik planlarda görüntü alınırken kontrast madde ihtiyacı doğabilir. Lumbosakral pleksus liflerine dışarıdan bası olabileceği gibi, bunlar sistemik inflamasyon ve malign proçeslerde diffüz infiltrasyona uğrayabilir. Psoas kasını tutan cerrahi, travma, kanama, abse ve tümör infiltrasyonu, direkt olarak lomber pleksus liflerine bası oluşturur. Retroperitoneal patolojiler ise, daha çok sakral pleksus liflerini etkiler. Psoas kasını direkt olarak tutan kolorektal, over, uterus ve serviks kökenli tümörler, neoplastik pleksopatiye neden olur. Meme, lenfoma, sarkomlar ve multipl miyeloma ise, bu alanı metastaz yolu ile etkiler. ${ }^{[5]}$ Sakroiliak eklemi tutan enfeksiyon ve artritler, pelvis ve kalça kırıkları, komplike pelvik cerrahi, sakral pleksus liflerini etkileyebilir. Kolorektal ve serviks tümörleri direkt invazyon oluşturabilirken, pelvis bölgesine uygulanacak radyasyon, bu alandaki sinirleri etkileyebilir (Şekil 2-4).

İskiofemoral mesafe (iskial tüberositaz ile femur küçük trokanter arası mesafe) mekanik olarak herhangi bir nedenle daraldığı zaman (osteofit, hamstring tendinopatisi, yapısal, vb.), kuadratus femoris kası ve çevresinde oluşan ödem-sıvı-inflamasyon nedeni ile, siyatik sinir basılanabilir. Oluşan tablo, iskiofemoral impingement olarak bilinir (Şekil 5-7). ${ }^{[6]}$

Etkilenen sinirde, akut dönemde hiperintensite ile birlikte kalınlaşma (ödem-inflamasyon) izlenirken, malign proçeslerde kalınlaşan sinirde düzensizlik ve kontrastlanma gözlenir. İnflamasyon-enfeksiyonlarda sinir kontrastlanırken, tümörlere göre daha düzenlidir.
Sinirden gelişen tümörler (nörinom gibi) ve sinire bası oluşturan primer lezyon-kitleler ise ayrıca görülür.

Semptomlar, etkilenen sinire göre gelişir; tek taraflı veya bilateral olabilir. il gili kaslarda, akut ve kronik döneme göre önceden tanımlanan bulgular ortaya çıkar.

\section{Femoral Sinir (iliakus Sendromu)}

Lumbosakral pleksusun kalın sinirlerinden olup, L2L4 sinir köklerinden oluşur ve iliopsoas, pektineus, kuadriseps (vastuslar ve rektus femuris) ve sartorius kaslarını innerve eder. Femoral sinir, pelviste ve inguinal kanal düzeyinde basıya uğrayabilir, ancak bu basının çoğu inguinal bağ altında olur. İnguinal bağ altından geçtikten sonra, femoral sinir, femur başı, vastus intermedius tendonu, psoas tendonu ve kalça eklem kapsülü ile yakın komşuluk halindedir. Total kalça protezlerinden sonra, femoral sinir etkilenebilir. Alt ekstremitenin fleksiyon, abduksiyon ve eksternal rotasyon pozisyonunda uzun süre tutulduğu pelvik girişimler, femoral sinirin inguinal bağ altında sıkışmasına neden olabilir. Pelvik kırıklar ve uyluğun akut hiperekstansiyonu, izole femoral sinir lezyonuna neden olabilir. Pelvik radyasyon, apendiks veya renal abse, hematom ve tümörler, femoral sinire bası yapabilir. ${ }^{[7]}$ Pelviste iliopsoas kas yırtık-hematomu, travma sonrası en sık nöropati nedenidir; travmada sinir direkt olarak da etkilenebilir. Pelviste kökenli kitlelerin direkt basısı ve iliopsoas bursa koleksiyonları sonucu oluşan basılar, diğer nedenlerdir. İnguinal herni onarımı ve femoral kateterizasyon sonrasında oluşan skar dokular, basıya neden olabilir. ${ }^{[8]}$

MR incelemede femoral siniri görmek zordur. Sıklıkla, transvers ve koronal planlarda alınacak T1A, STIR ve MR nörografi sekanslarında, pelvis-inguinal kanal ve uyluk boyunca izlenebilir (Şekil 8). ${ }^{[5]}$
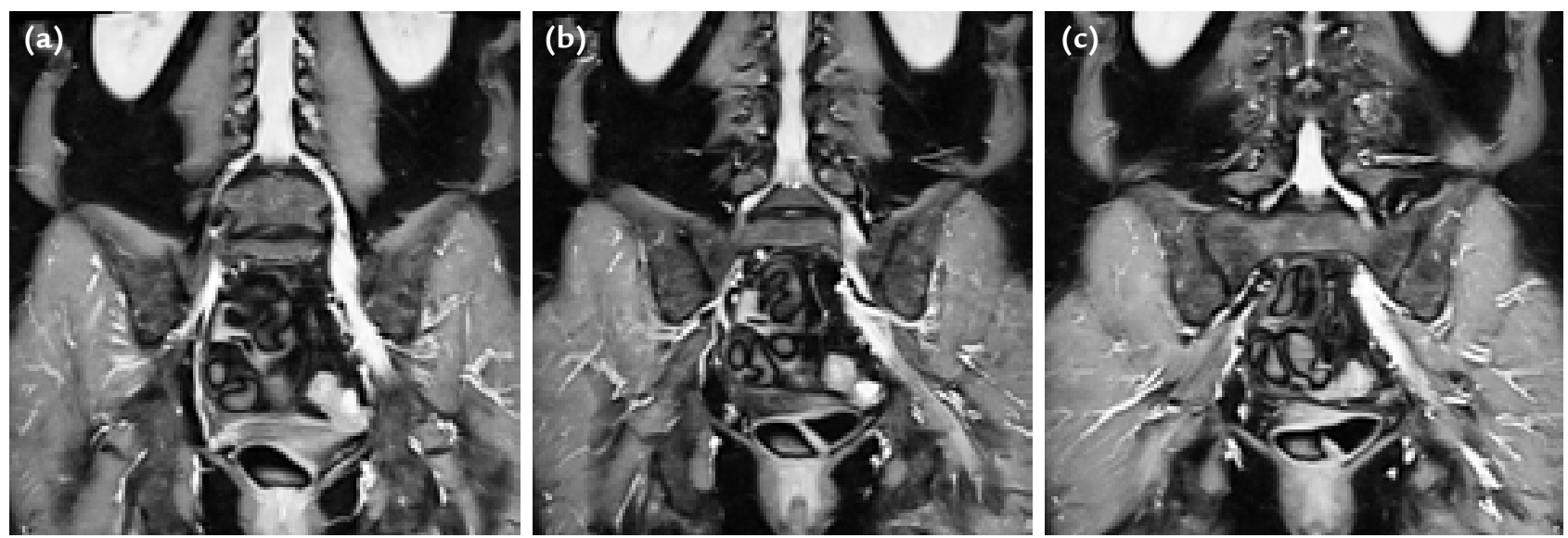

Şekil 2. a-c. Sol lumbosakral idiyopatik inflamatuvar pleksopati. MR nörografi incelemesinde, sol taraf pleksus liflerinde genel kalınlaşma ve hiperintensite izleniyor. 

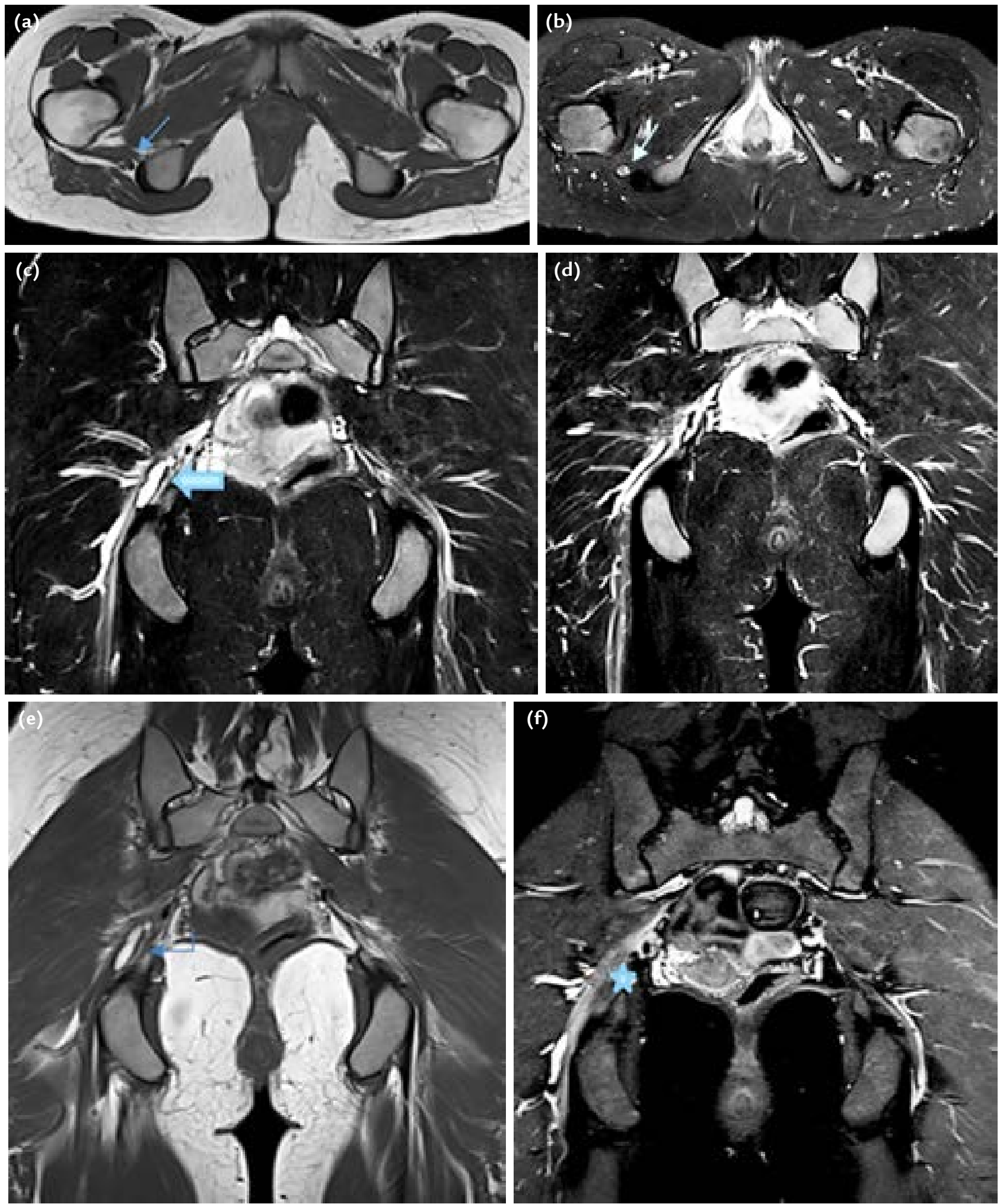

Şekil 3. a-f. Sağ siyatik nöropati. illk görüntüde (T1A transvers), sağ kuadratis femoris ve gluteal kasların genel olarak ince-atrofik olduğu gözleniyor (a). Sağ siyatik sinir (sağ ince ok), simetriğine göre kalın ve (STIR transvers) hiperintensite gösteriyor (b). STIR koronal $(\mathbf{c}, \mathbf{d})$ görüntülerde, siyatik sinirin proksimal komşuluğunda, hiperintens sinyal özelliğinde, fuziform, ince septa içeren, lobüle konturlu kitle (kalın ok) izleniyor. Sağ siyatik sinir, normalden kalın ve hiperintens olarak görülüyor. T1A koronal (e) görüntüde lezyon hiperintens sinyal özelliğinde izlenirken (açılı ok), son koronal görüntüde (MR nörografi) (f), sağ siyatik sinir normalden daha belirgin, kalın ve hiperintens olarak gözleniyor (yıldız). Kitle, endometriyoma olarak raporlanmış ve cerrahi sonrası bu sonuç doğrulanmıştır. 

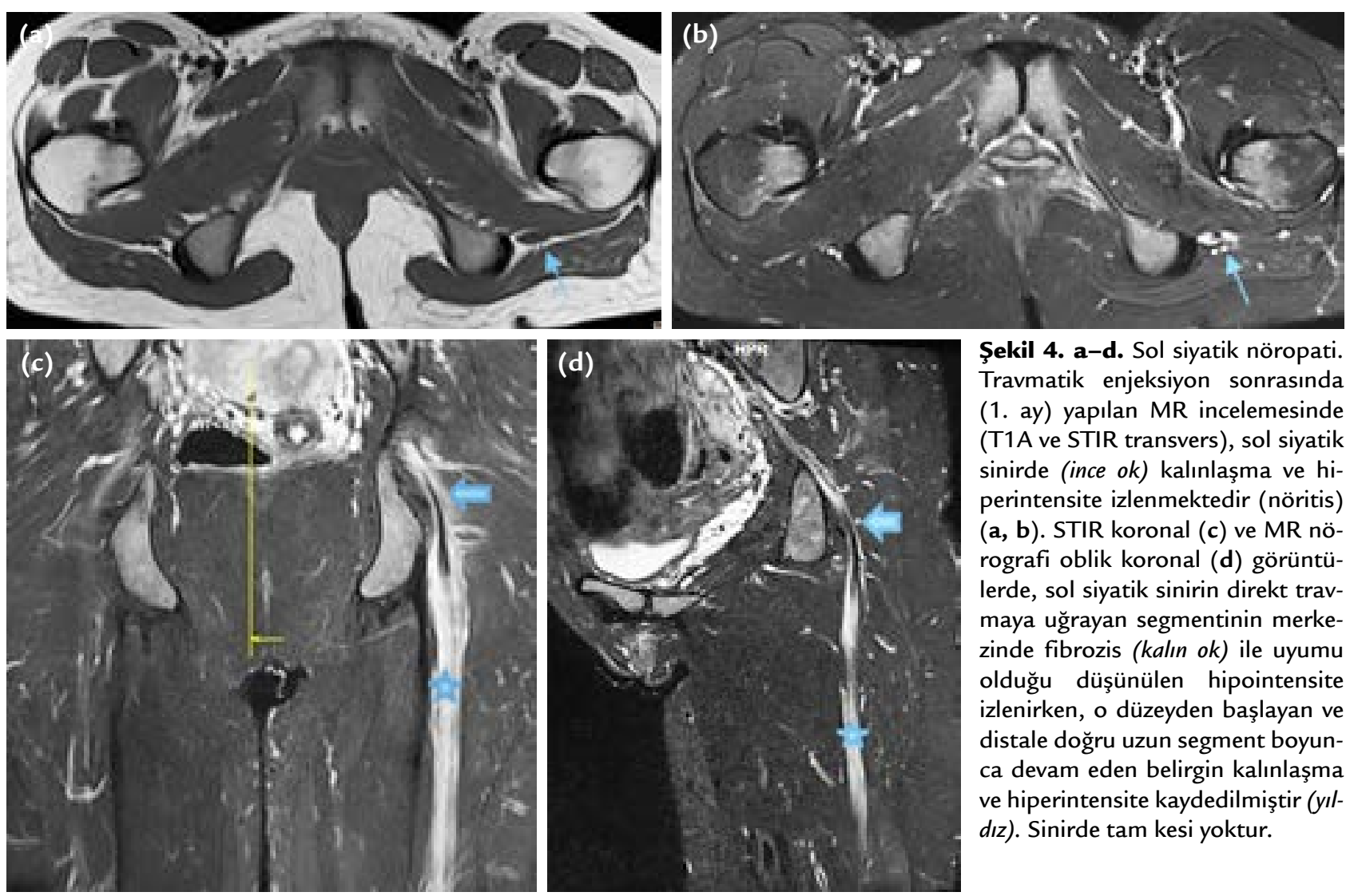

Şekil 4. a-d. Sol siyatik nöropati. Travmatik enjeksiyon sonrasında (1. ay) yapılan MR incelemesinde (T1A ve STIR transvers), sol siyatik sinirde (ince ok) kalınlaşma ve hiperintensite izlenmektedir (nöritis) (a, b). STIR koronal (c) ve MR nörografi oblik koronal (d) görüntülerde, sol siyatik sinirin direkt travmaya uğrayan segmentinin merkezinde fibrozis (kalın ok) ile uyumu olduğu düşünülen hipointensite izlenirken, o düzeyden başlayan ve distale doğru uzun segment boyunca devam eden belirgin kalınlaşma ve hiperintensite kaydedilmiştir (yIdiz). Sinirde tam kesi yoktur.
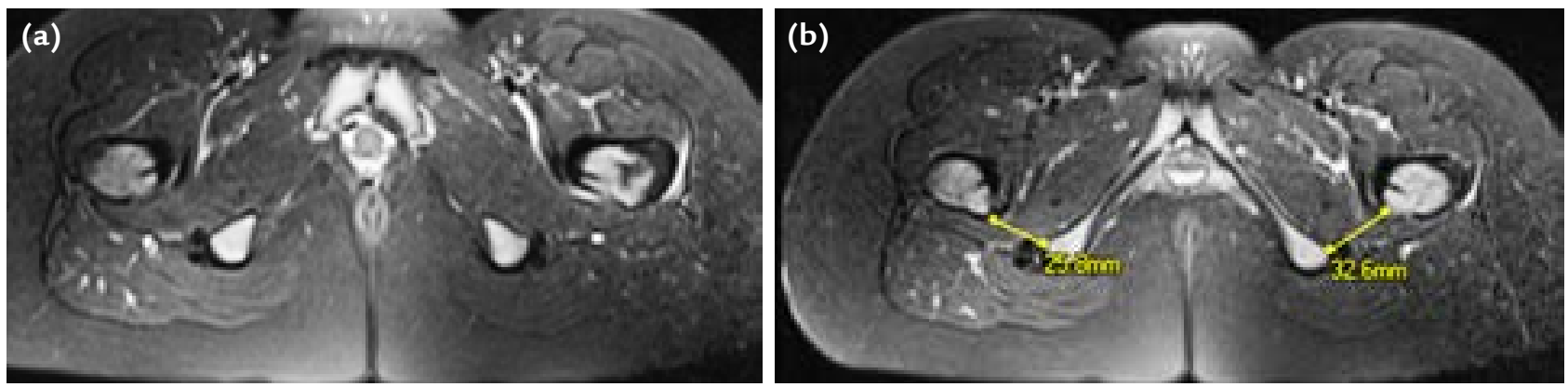

Şekil 5. a, b. Sağ iskiofemoral impingement. STIR transvers görüntülerde, sağ iskiofemoral mesafenin simetriğine göre anlamlı olarak dar olduğu izleniyor.
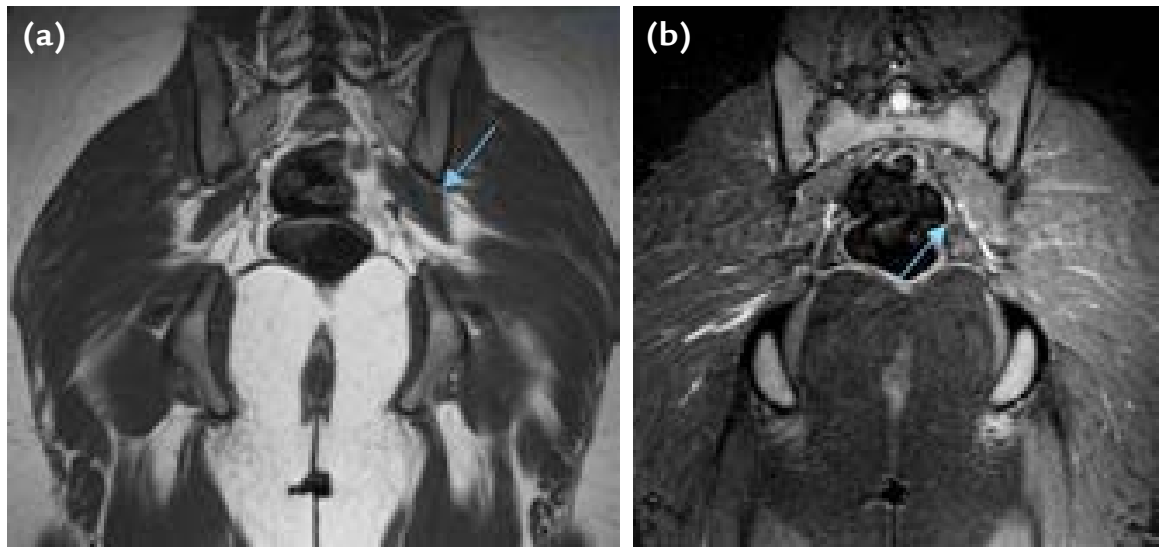

Şekil 6. a, b. Sol piriformis sendromu. T1A koronal (a) ve STIR koronal (b) görüntülerde, sol piriformis kasında anlamlı kalınlaşma (hipertrofi) izleniyor. 

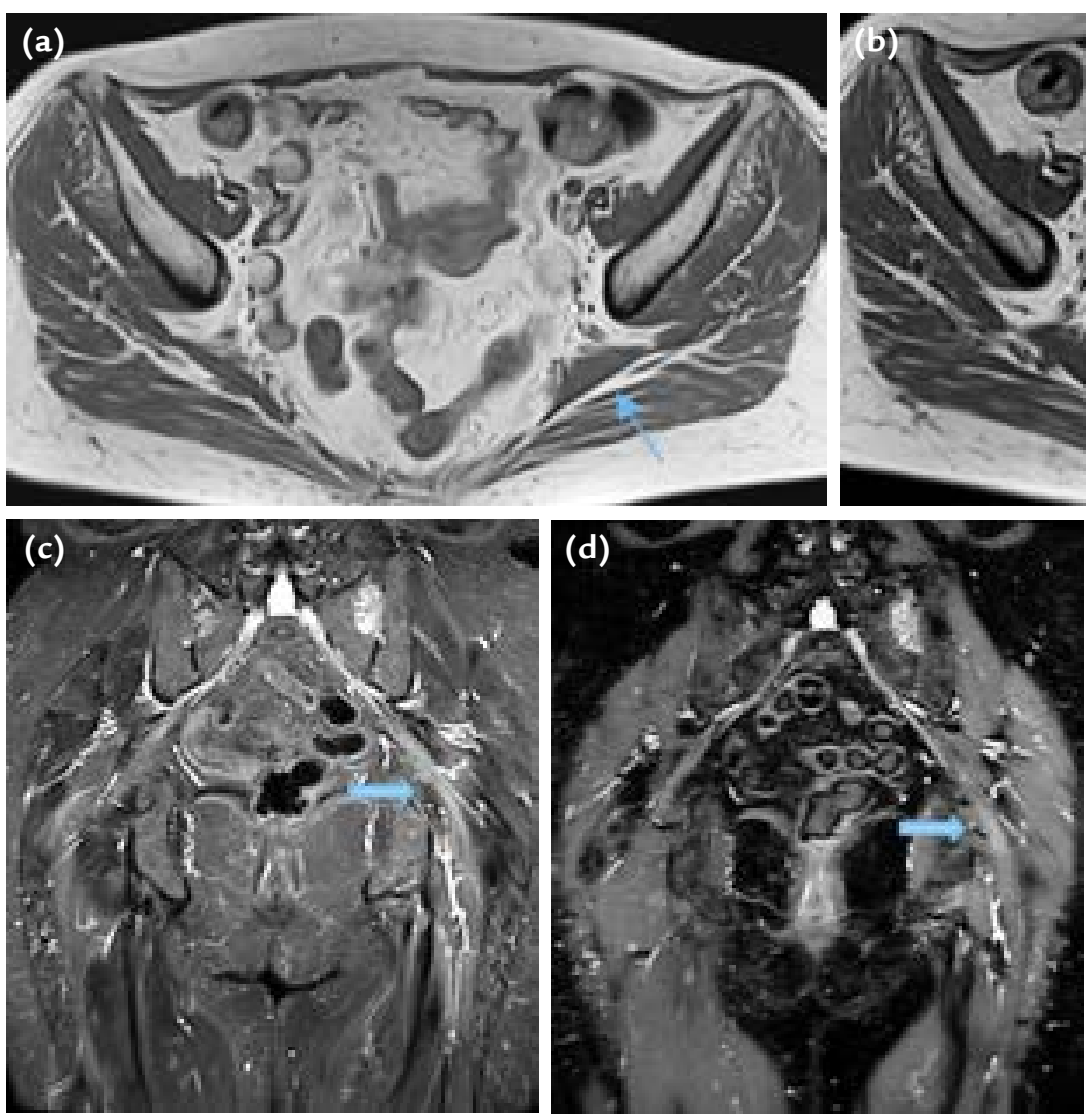

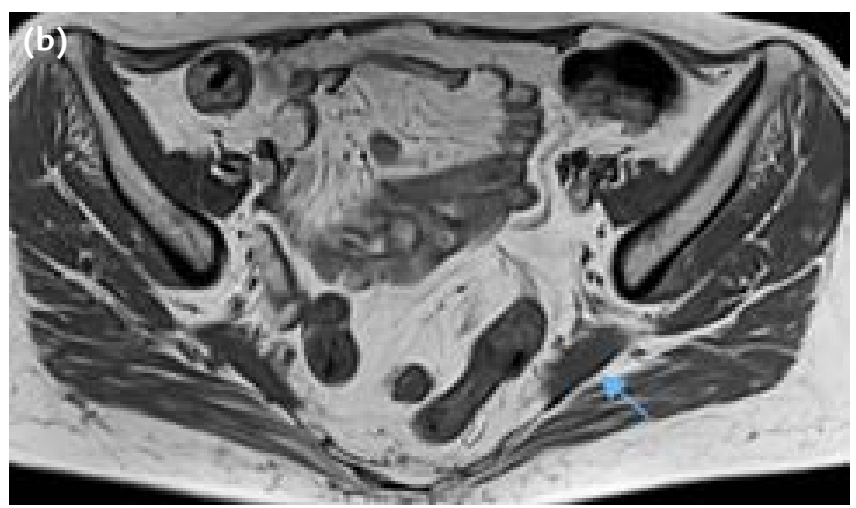

Şekil 7. a-d. Sol piriformis sendromu. T1A transvers görüntülerde $(\mathbf{a}, \mathbf{b})$ sol piriformis kasında (düz ok) hipertrofi izlenirken STIR koronal (c) ve MR nörografi (d) görüntülerde, sol siyatik sinirde (kalın ok) kalınlaşma ve hiperintensite gözleniyor.
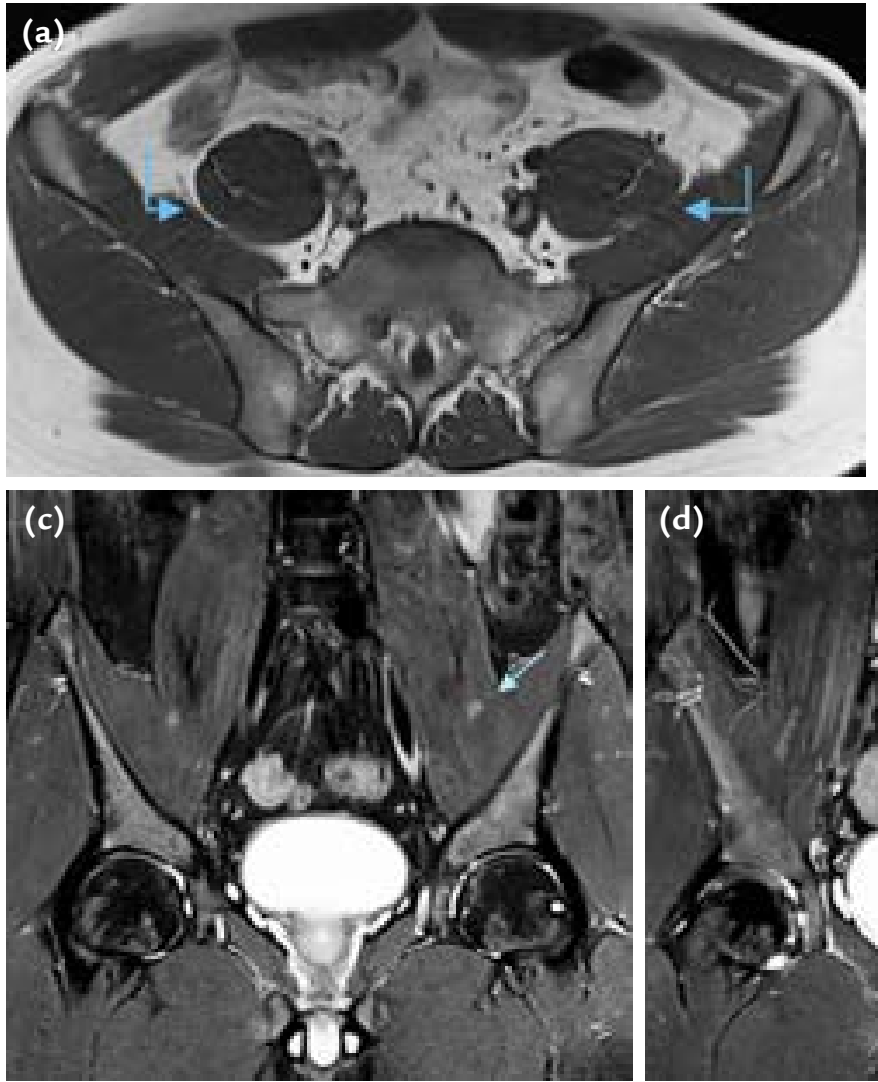

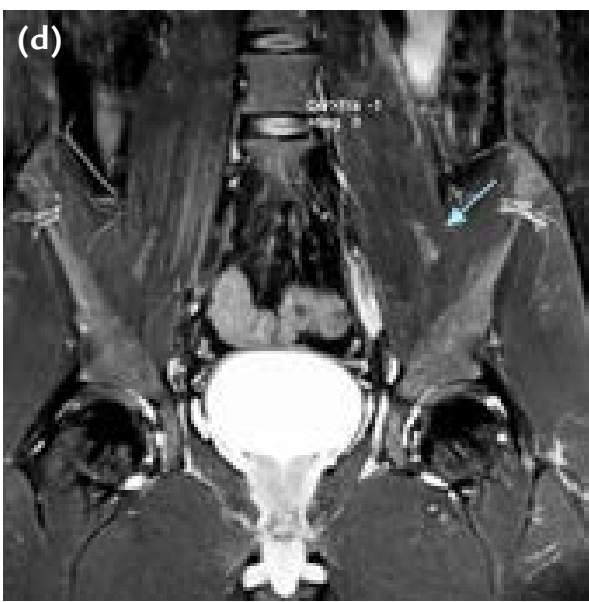

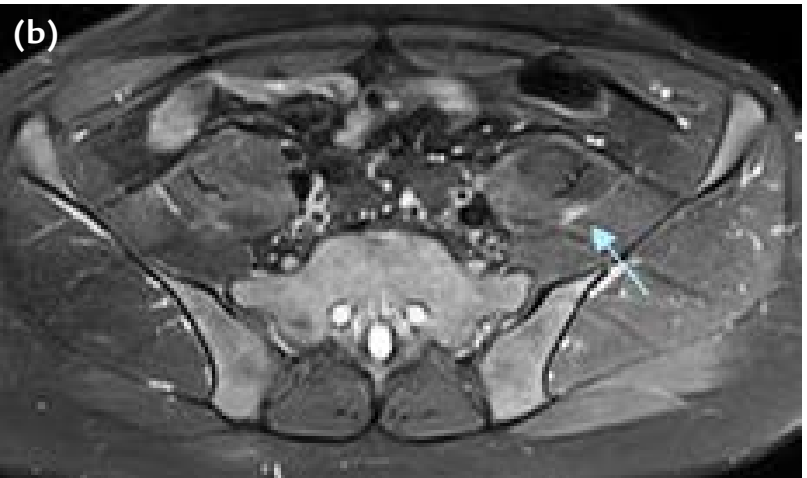

Şekil 8. a-d. Sol femoral sinir nöropatisi. T1A transvers (a) ve STIR transvers (b) görüntülerde, solda femoral sinirin psoasiliakus kasları arasında sıkıştığı, STIR sekansında ise sinirde hiperintensite izlenmektedir. Illk görüntüde (a), sol psoas kası simetriğine göre hafif kalın olup iki kas arası yağ planı solda silinmiştir (açılı ok). MR nörografi incelemesinin koronal kesitlerinde $(c, d)$ ise, sol siyatik sinirde kalınlaşma ve hiperintensite daha belirgin olarak karşımıza çıkmaktadır (ince oklar). 


\section{Lateral Kutanöz Sinir}

Bu nöropati, meraljia parestetika olarak bilinir ve inguinal bağ seviyesinde meydana gelir. Orta yaş grubunda daha sıktır. Etiyoloji, intrapelvik, ekstrapelvik ve mekanik nedenler olarak üç gruba ayrılabilir. İntrapelvik nedenler, gebelik, abdominal tümörler, uterus kitleleri, abdominal aort anevrizması, divertikülit veya apandisit gibi yer kaplayan kitlelerdir. Ekstrapelvik nedenler arasında, spina iliaka anterior superior bölgesine olan travmalar, emniyet kemeri basısı, kemer-korse basısı, obezite ve assit sayılabilir. Mekanik faktörler ise, uzun süre oturma, ayakta durma veya bacak uzunluk farklarıdır. Diabetes mellitus gibi sistemik hastalıklar da meraljia parestetikaya neden olabilir.

Lateral femoral kutanöz sinirin inguinal bağ altındaki seyrinde ya da fasya latayı delerek geçtiği kesimdeki seyrinde oluşan sıkışması ile gelişir. MR görüntülerde, sıkışan sinirin boyut ve sinyalinde farklılık ile etiyolojik neden görülebilir. ${ }^{[9]}$

\section{Obturator Sinir}

Obturator sinir, L2-L3 ve L4 sinirlerinin ventral kısımlarından, psoas kası içerisinde oluşur. Sinir, pelviste obturator kanal boyunca uzanır ve obturator foramenden uyluk üst kısmına uzanır; anterior ve posterior dalları vardır.

Obturator sinir sıkışmasına neden olan etmenler arasında, pelvik-asetabular kırıklar, travma sonrası gelişen hematomlar, miyositis ossifikans, pelvik tümörler, anevrizma, enfeksiyon ve inflamasyonlar gibi nedenler yer alır.

MR incelemede, obturator sinire yönelik alınan transvers, sagittal ve koronal planlardaki görüntülerde, patolojik bulgular görülebilir. MR görüntülerde, sinirde oluşan değişiklikler ile bası oluşturan etmen izlenebilir. Yine, etkilenen kaslarda oluşan değişiklikler, akut ve kronik evreye göre ayrıntılı olarak görülür. ${ }^{[10]}$

\section{Siyatik Sinir}

Siyatik sinir, vücudun en kalın siniridir ve L2-S3 sinir köklerinden oluşur. Pelviste ana siyatik sinir, piriformis kasının anteriorunda izlenirken, gluteus maksimus kasının önünde ve adduktor magnus kasının arkasında seyreder (Şekil 9).

MR incelemede, ana siyatik sinirin çevresinde genelde yağ yastıkçığı bulunurken, normal sinir oldukça kalın olduğundan, sinir fasikülleri seçilebilir. Ana segment, uyluk üst bölümünde tibial ve peroneal dallarına ayrılır; tibial segment daha kalındır.

Siyatik sinir tuzak nöropatisinde, travma önemli bir yer tutar. Peroneal segmentin çevresinde daha az yağ yastıkçı̆̆ı bulunduğundan ve iki noktada sabitlendiğinden (siyatik foramen ve fibula başı), travmalardan daha çok etkilenir. Tibial segment ise, sadece siyatik foramen düzeyinde sabitlenir. Total kalça protezi, direkt travma ve uzamış alt ekstremite (uyluk) gerilmeleri, nedenler arasındadır. ${ }^{[11]}$

Konvansiyonel MR ve MR nörografi incelemelerinde, siyatik sinirde kalınlaşma ve sinyal artışı izlenirken, çevre yağ doku planı silinir. Basıya neden olan tümör, abse, inflamasyon, ödem, skar doku, hematom ve kas hipertrofileri gibi nedenler tespit edilir. Alt ekstremitede etkilenen kaslardaki değişiklikler, akut ve kronik evrelere göre izlenir. ${ }^{[12]}$ Tibial segment biseps femoris uzun başı, semitendinöz, semimembranöz ve adduktor magnus kaslarını innerve ederken, peroneal segment biseps femoris kası kısa başını innerve eder.

Piriformis sendromu, siyatik sinirin piriformis kası tarafından büyük siyatik çentikte sıkıştırılmasına bağlı gelişir. Piriformis kasının hipertrofisi (yürüyüş bozuklukları, lomber problemler ve kalça eklemi fleksiyon deformitesi), inflamasyon-enfeksiyonu (komşuluğundaki alt lomber vertebra, sakroiliak eklemler ya da iliopsoas kasından olan enfeksiyon ve inflamasyonun bu bölgeye yayılması), spazm-kontraktür (serebral palsi gibi), travma sonrasında oluşan hematoma veya skar doku gelişimi, kasın lokal iskemisi, kasın akut veya kronik uzun süreli gerilmeleri sonucunda, ana siyatik sinirin

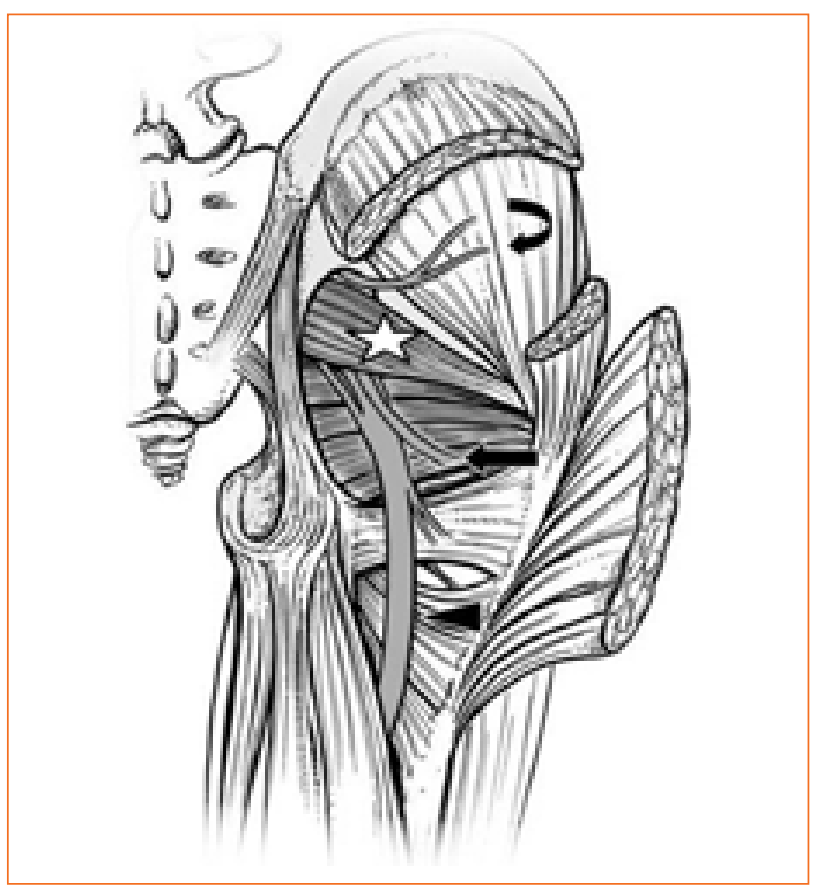

Şekil 9. Siyatik sinir (ok başı), superior gluteal sinir (eğri ok), inferior gluteal sinir (düz ok), piriformis kası (yıldız). 
sıkışması sonucunda gelişir. Kas asimetrileri, $4 \mathrm{~mm}$ ve üzerinde anlamlı bulunmuştur. ${ }^{[4]}$ Aksesuvar piriformis kasları izlenebilir.

Yapılan çalışmalarda, kas hipertrofisine bağlı piriformis sendromunda, asimetrik kas hipertrofisinin özgüllüğü \%66, duyarlılı̆ı ise \%46 olarak bulunmuştur. Semptomatik hastaların \%88'inde ise, tek taraflı sinir ödemi (aynı tarafta) izlenir. Aynı tarafta kas hipertrofisi ve sinir ödeminin birlikte izlenmesi durumda, özgüllük \%93 düzeyine çıkmaktadır. ${ }^{[13]}$

\section{Safenöz Sinir}

Femoral sinirin en uzun dalıdır ve saf duyu lifleri taşır. Uzun seyri nedeniyle, uyluk ve bacakta birçok seviyede basıya uğrayabilir. Safenöz sinir en sık, femur mediyal kondilin $10 \mathrm{~cm}$ proksimalinde, Hunter kanaldan çıkarken sıkışır. Cerrahi sırasında, diz ve bacağın iyi korunmaması nedeniyle yaralanabilir. Nöral kaynaklı kitleler, femoral damar basısı, direkt travma, pes anserinus bursiti, variköz ven operasyonu, mediyal diz artrotomileri ve menisküs tamirlerinde yaralanabilir. MR incelemede, sıkışmaya neden olan etkenler izlenirken, sinirde kalınlaşma ve sinyal artışı görülür. Sinir bütünüyle duyusal lifler taşıdığından, herhangi bir kasa ait denervasyon ödemi görülmez. ${ }^{[14]}$

\section{Superior ve İnferior Gluteal Sinirler}

Superior gluteal sinir, L4-L5 ve S1 sinirlerin posterior köklerinden, inferior gluteal sinir ise L5-S1 ve S2 sinirlerinin posterior köklerinden oluşur. Gluteal kasları etkileyen ve bu sinirleri basılayan benzer nedenlerle (total kalça protezi, travma, hematoma, kitleler, vb.), tuzak nöropatileri oluşur. Superior gluteal siniri, ayrıca tensor faysa lata kası da etkiler. ${ }^{[15]}$

\section{Ortak Peroneal Sinir (Şekil 10)}

Siyatik sinirden popliteal fossada ayrilan ortak peroneal sinir, fibula başı arkasından ve fibular tünelden geçtikten sonra yüzeyel ve derin olmak üzere iki dala ayrılır. Alt ekstremite travmalarında en sık yaralanan sinirdir ve yüzeyel seyir gösterdiğinden, en çok fibula başı düzeyinde yaralanır.

Kronik bacak bacak üstüne atmada, özellikle bilinç sorunu olanlarda veya uzun süre immobil olanlarda ve anestezi altında tutulan hastalarda, eksternal bası ile sinir sıkışabilir. Kırıklar (özellikle fibula başı), laserasyonlar, cerrahi sonrası sütür, diz dislokasyonları, tibial osteotomiler, total diz ve kalça protezleri ve artroskopileri yanı sıra, tümörler, hematoma, abse, kas hipertrofileri ve skar doku nedeniyle bası oluşabilir. Aşırı kilo kaybı nedeniyle fibula başındaki yağ dokusunun kaybı ve buna bağıı olarak, eksternal basıya duyarlıı̆ı̆ın

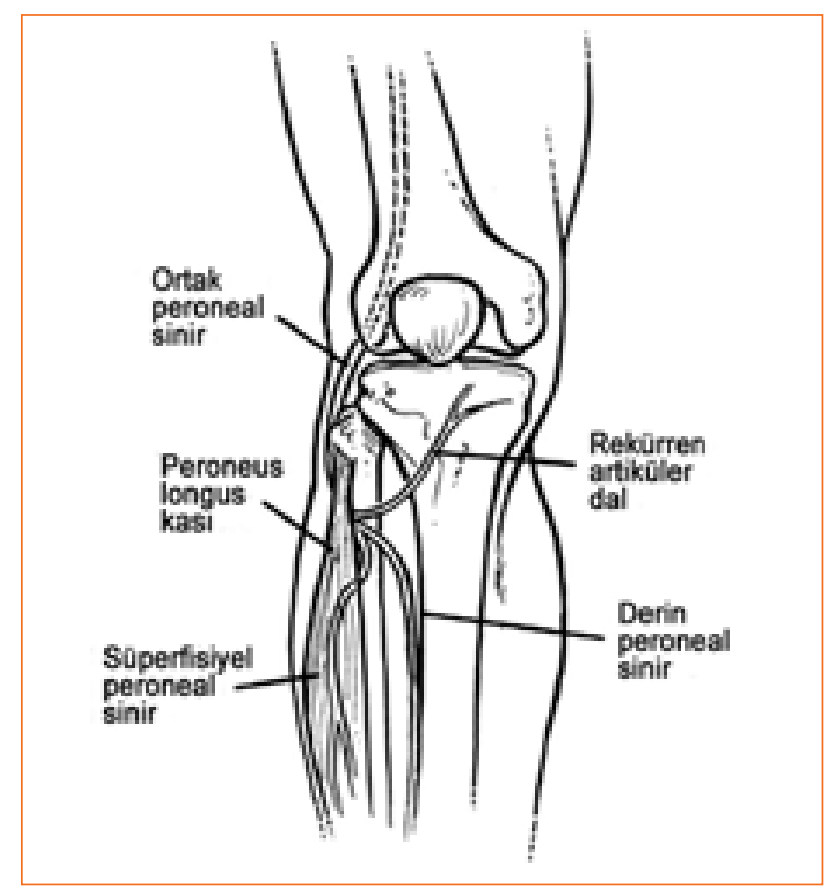

Şekil 10. Ortak peroneal sinir ve dalları.

artması nedeniyle olabilir. Yanlış alçı ve eksternal cihazlar, peroneal sinir basısına yol açabilir. ${ }^{[16,17]}$

MR incelemelerinde basıya neden olan etmen tespit edilirken, basıya uğrayan sinirde ortaya çıkan değişiklikler ve etkilenen kaslardaki (anterior ve lateral kompartman) değişiklikler de görülür. Kronik krural ağrıya neden olan stres fraktürleri, kronik kompartman sendromu ve popliteal arter tuzak sendromu ayırıcı tanıları yapilır.

\section{Derin Peroneal Sinir (Şekil 11)}

Derin peroneal sinir, en sık olarak, ayak bileği düzeyinde yer alan superior ekstansör retinakulum altında sıkışır ve bu tabloya anterior tarsal tünel sendromu denir. Sinir, bu bölgede, kalınlaşmış retinakulum ve tendonlar arasında sıkışabileceği gibi, osteofit, ekzositoz ve gangliyon kisti gibi yer kaplayan lezyonlar nedeniyle etkilenebilir. Tekrarlayan dorsifleksiyon ve plantar fleksiyon, mekanik bası oluşturabilir. Derin peroneal sinirin proksimal düzeyde basısı, kruris proksimal kesiminde yer kaplayan lezyonlar, kas hipertrofileri - aksesuvar kaslar, cerrahi girişimler ve atletlerde, kronik anterior egzersiz ile ilişkili kompartman sendromu nedeniyle olabilir. ${ }^{[18]}$

MR incelemede, etkilenen derin peroneal sinir diğer yapılardan ayrı olarak, kalınlaşmış ve hiperintens olarak seçilebilir. Gangliyon kisti gibi yer kaplayan 


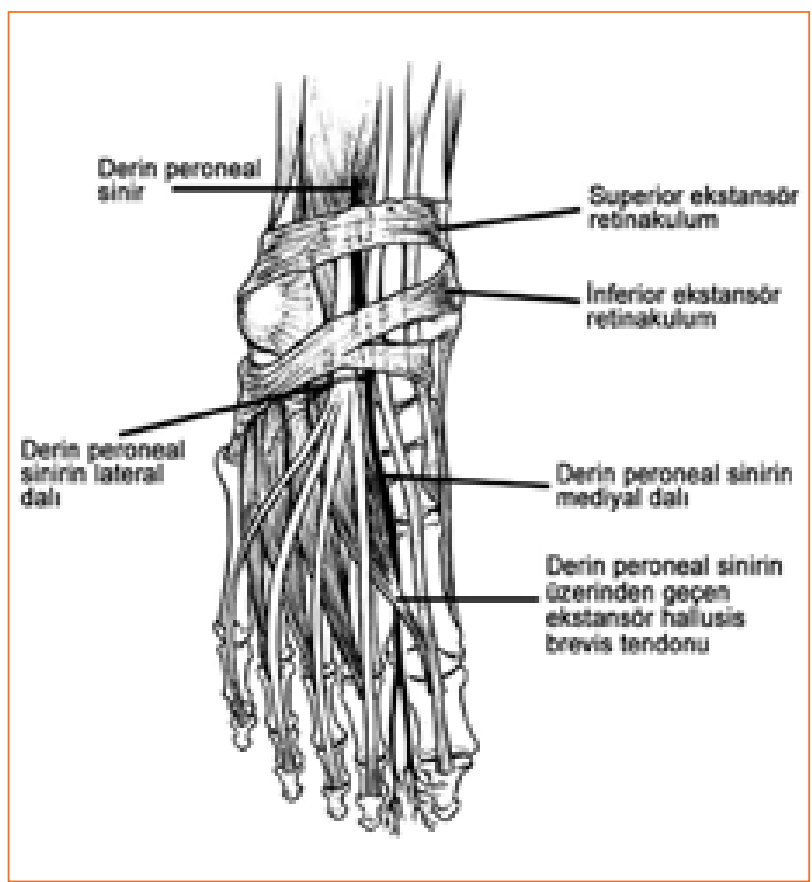

Şekil 11. Derin peroneal sinir.

lezyonlar izlenirken, aksesuvar kemikçikler, osteofitler de görülür. Etkilenen kaslarda denervasyon değişiklikleri tespit edilir.

\section{Yüzeyel Peroneal Sinir (Şekil 12)}

Kruriste lateral seyreden yüzeyel peroneal sinir, ayak bileği proksimalinde ikiye ayrılır. Lokal travma ve kompresyonlar, yüzeyel dalın en sık yaralanma nedenidir. Tekrarlayan ayak bileği burkulmaları, uzun süre diz üstünde veya çömelerek oturma, belirli pozisyonda dans, direkt travma, inversiyon burkulmaları nedeniyle, sinir bası altında kalabilir. Kal dokusu, kitleler ve diğer yer kaplayan lezyonlar, etiyolojide rol oynar. Travma ardından krural fasyada oluşan yırtıklar sonrasında oluşan defektlerden, kas herniyasyonları oluşabilir. Oluşan kas fitıkları, sinire bası yapabilir. ${ }^{[7]}$

MR incelemede, basiya neden olan etmen, sinirde oluşan patoloji ve etkilenen kaslardaki değişiklikler görülür. Dinamik olarak yapılacak MR incelemede (dorsifleksiyon ve plantar fleksiyon), kas fitıkları tespit edilebilir. ${ }^{[3]}$

\section{Posterior Tibial Sinir}

Siyatik sinirin tibial komponentinden köken alan posterior tibial sinir, popliteal bölgede ayrılır, gastroknemius ve soleus kaslarının altından seyreder. Ayak bileği eklemi seviyesinde yüzeyel seyreder; mediyal malleolün

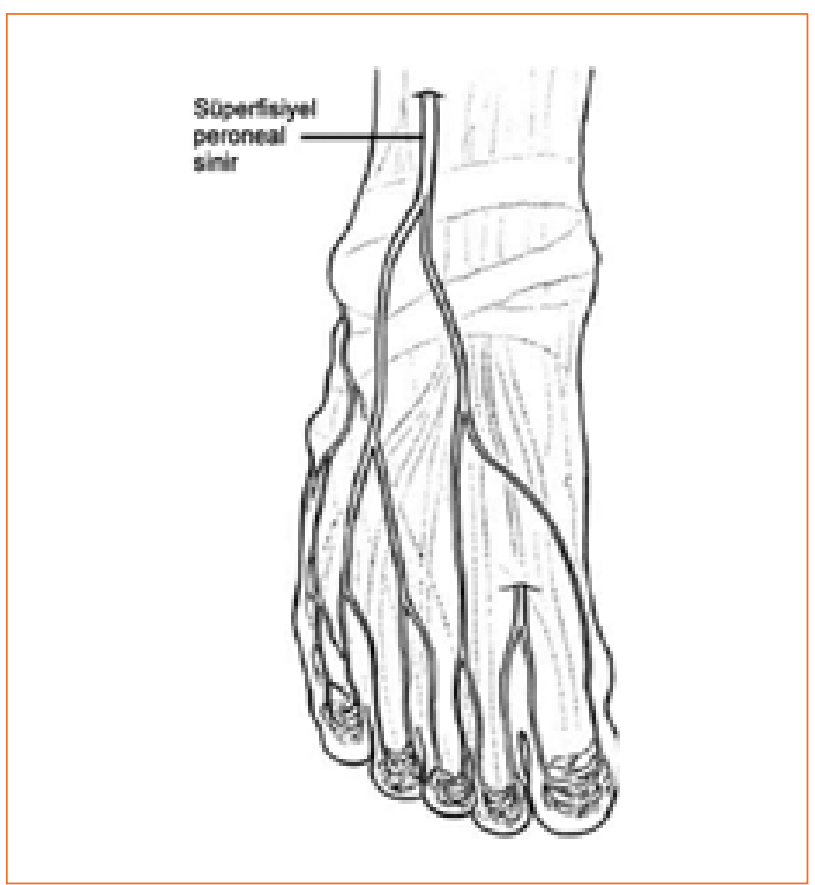

Şekil 12. Yüzeyel peroneal sinir.

arkasındadır. Burada, mediyal ve lateral plantar dallar ile kalkaneal dala ayrilır. ${ }^{[16,17]}$

Proksimal tibial tuzak nöropati, popliteal fossa içinde, popliteus kası üzerinde ve soleus kası tendinöz arkı altındaki sinir seyri sırasında gelişir. Popliteal fossada hematoma, sinir tümörleri ve Baker kistleri, siniri bu lokalizasyonlarda sıkıştırabilecek nedenlerdir. MR görüntülerde, tibial sinire popliteal fossa içinde oluşan bası ile gastrokinemus ve popliteus kaslarında gelişen denervasyon değişiklikleri izlenebilir. ${ }^{[3]}$

\section{Tarsal Tünel Sendromu}

Posterior tibial sinir, en sık ayak bileği distalinde sıkışır (Şekil 13). Tarsal tünel sendromu, tibial sinirin bir veya birden fazla dalının tarsal tünelden geçtiği pasajda dışardan basılanması sonucunda oluşur.

Tarsal tünel, mediyal malleolün posteromediyalinden başlar ve fleksör retinakulum ile kalkaneus ve talus arasında yer alır. Sinir basısına; gangliyon kisti, lipoma, nörinoma, ödem, sinoviyal hipertrofi, fibrozis, osteokondroma, malign tümörler, tarsal koalisyon, kas-tendon anomalileri (aksesuvar yapılar), varis, osteofit ve kemik parçalar neden olabilir. Tarsal tünelin volümü yapısal olarak küçük ise bası etkisi daha belirgin olurken, vertikal talus ve orta ayaktaki valgus deformiteleri gibi anomaliler, bu durumu kolaylaştırır. Tenosinovit, tendon rüptürü, tekrarlayan travmalar, 


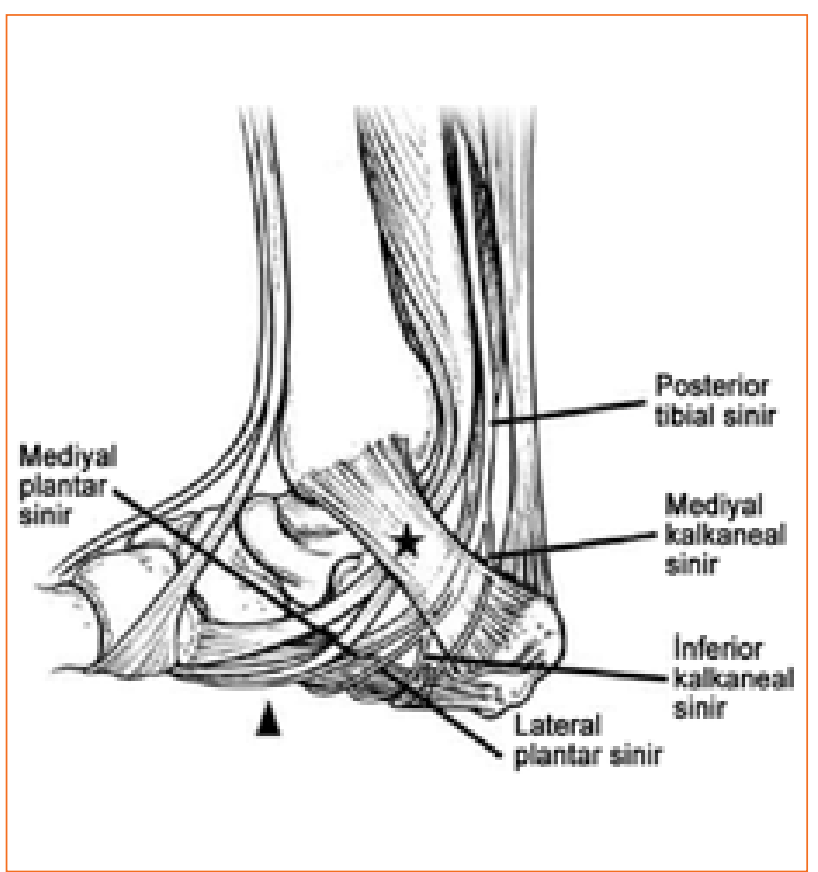

Şekil 13. Posterior tibial sinir (yıldız, fleksör retinakulum).

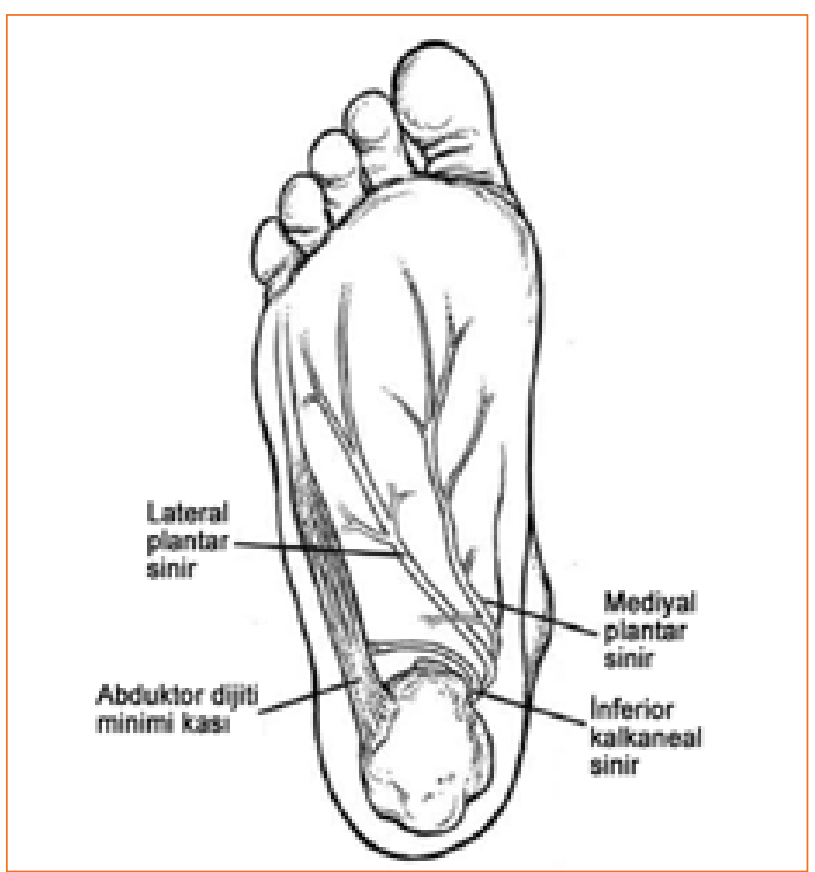

Şekil 14. Posterior tibial sinirin dalları. obezite, ankilozan spondilit, akromegali ve talokalkaneal anomaliler nedeniyle, tarsal tünel sendromu oluşabilir. Diyabet, romatoid artrit vb. sistemik hastalıklarda görülebilir. ${ }^{[7]}$

Posterior tibial sinirin lateral plantar dalı sıkıştığında ağrı topukta olurken, mediyal dal sıkıştığında ağrı mediyal arkta olur (Şekil 14). ${ }^{[19]}$

MR inceleme, tarsal tünel anatomisi ile sendroma yol açan nedenleri ve oluşan patolojiyi ayrıntılı olarak gösterebilirken, ayırıcı tanı konusunda da yeterli düzeyde bilgi verir. Ayrıca, cerrahi tedavi sonrasında oluşabilecek komplikasyonları değerlendirmede, diğer görüntüleme tekniklerine göre daha üstündür. Tibial sinir ve dallarında boyut ve intensitede artış, yer kaplayıcı lezyonlar ve ayağın plantar kaslarında denervasyon ödemi izlenebilir (Şekil 15).

\section{Baxter'ın nöropatisi}

Tibialis posterior sinirin inferior kalkaneal dalı basısına bağlı gelişen tuzak nöropatisidir. Sıkışmanın en sık nedenleri arasında, özellikle koşucularda, hipertrofiye olmuş abduktor hallusis longus kası, sinirin mediyal kalkaneal tüberositazın anteriorunda seyri, kalkaneus inferiorunda yerleşimli osteofit ve plantar fasyada kalınlaşma - plantar fasiitis vardır. MR görüntülerde sıklıkla, abduktor dijiti minimi kasında erken evrede denervasyon ödemi ve geç evrede yağlı atrofi izlenir (Şekil 16).

\section{Koşucu Ayağı (Jogger's Foot)}

Medyal plantar sinirin, abduktor hallusis kası ile ayak plantar kesiminde çapraz yapan fleksör hallusis longus ve dijitorum longus tendonları arasında sıkışmasına bağlı gelişir. Etiyolojiler arasında, ayak arka kesim valgus deformitesi ve koşarken aşırı pronasyonu ve yüksek yerleşimli mediyal ark vardır. ${ }^{[20]}$

MR görüntülerde, akut veya kronik evreye göre, abduktor hallusis, fleksör dijitorum brevis, fleksör hallusis brevis ve birinci lumbrikal kaslarında denervasyon ödemi veya atrofisi izlenir.

\section{Morton'un Nöroması (İnterdijital Nöropati)}

Ayak distalinde, transvers intermetatarsal bağlar altında, interdijital sinirlerin kronik olarak sıkışması sonucunda gelişir. Kadınlarda, ikinci ve üçüncü intermetatarsal aralıkta daha sık görülür. Yürüyüşün basma fazı sonunda, sinir, plantar bölge ile intermetatarsal bağ distal kenarı arasında sıkışır. İskemi, inflamasyon, yumuşak doku travması, tümör, adale imbalansı veya fibröz doku buna neden olabilir. Önayak deformiteleri, çekiç parmak, yüksek topuklu ve dar ayakkabılar, metatarsofalangeal eklemleri dorsifleksiyonda tutarak, ağırlığın bu bölgeye yoğunlaşmasına neden olabilir. ${ }^{[21]}$

MR incelemede, ayak distalinde plantar tarafa doğru uzanım gösteren, intermetatarsal aralığı 


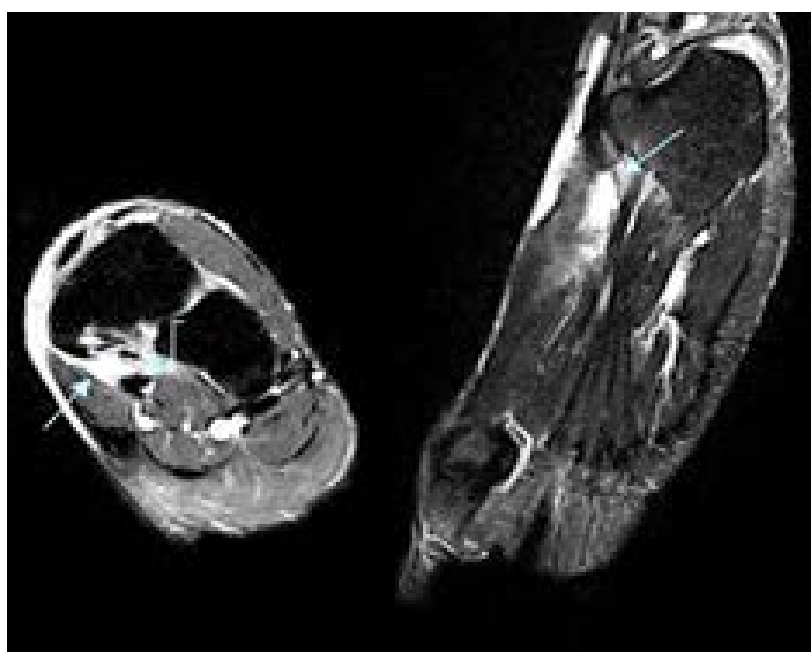

Şekil 15. Tarsal tünel sendromu. STIR transvers ve koronal görüntülerde, posterior tibial sinirin mediyal dalına bası oluşturan tendon kılıfı kökenli gangliyon kisti izleniyor (düz ok, gangliyon kisti; açılı ok, sinir).

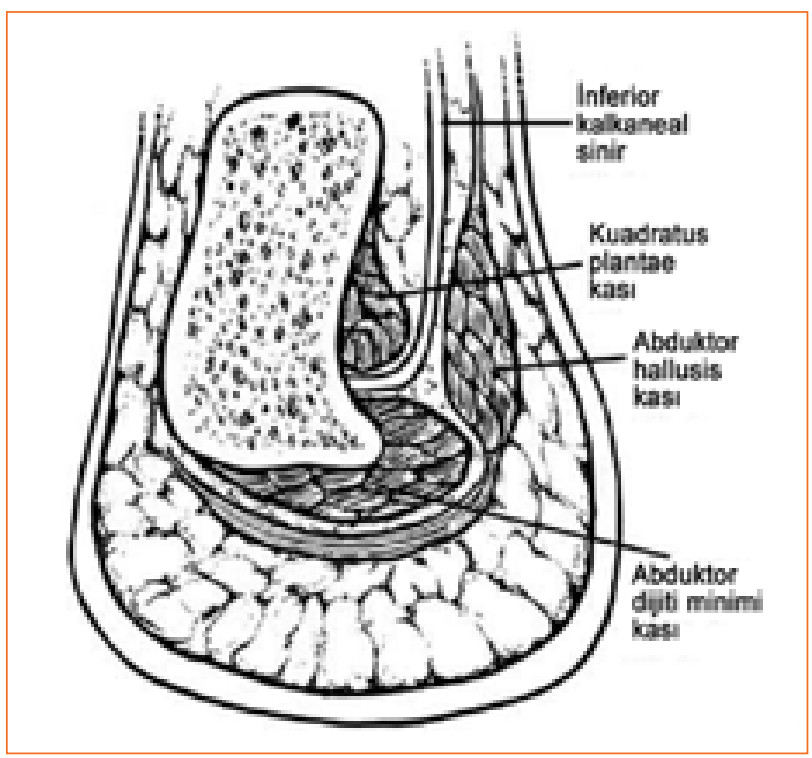

Şekil 16. İnferior kalkaneal sinir.
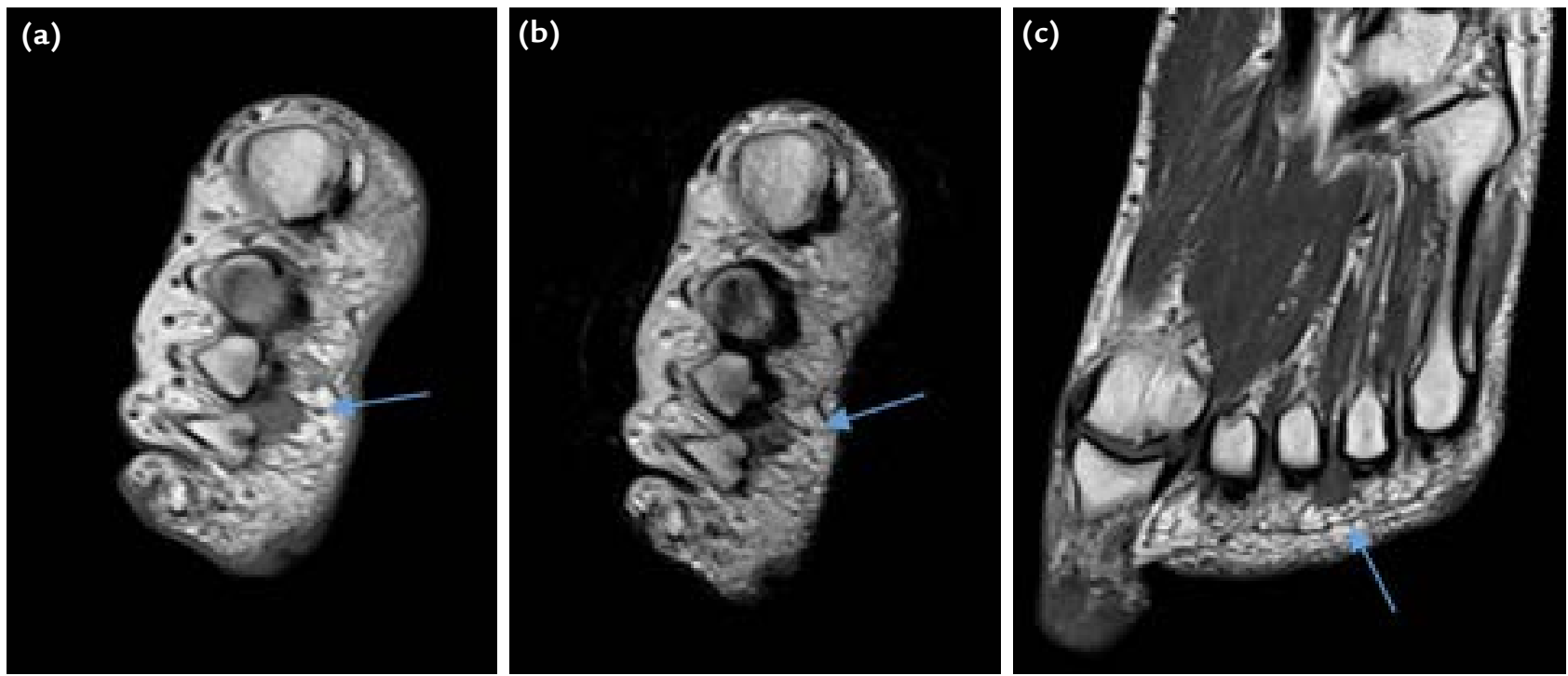

Şekil 17. a-c. Morton nöroma. T1 (a), T2A transvers (b) ve T1A koronal (c) görüntülerde, 3. ve 4. metatars başları arasında kitle izleniyor.

ilgilendiren yumuşak doku kitlesi görülür (Şekil 17). Tarif edilen yumuşak doku, T1A görüntülerde kas ile aynı intensitede olup, STIR sekanslarda değişken hiperintensite gösterir. Kontrast sonrası, çoğu zaman kontrastlanırken, çevresel reaktif inflamasyon bulguları izlenmektedir. [21]

\section{ÜST EKSTREMITE TUZAK NÖROPATILERI}

Üst ekstremitede brakiyal pleksusun dalları -muskülokutanöz sinir, supraskapular sinir, aksiller sinir, unlar sinir, radyal sinir ve bu sinirin derin dalı olan posterior interosseöz sinir, median sinir ve dalları, anterior interosseöz sinir- değişik yerlerde basıya uğrayabilir. Bu sinirlerin özellikle basıya uğradığı anatomik bölgelere göre, oluşan tuzak nöropatiler, özel isimler alır. ${ }^{[22]}$

\section{Brakiyal Pleksus Nöropatisi (Şekil 18)}

$\mathrm{Bu}$ nöropati, torasik outlet sendromu (TOS) ve Parsonage-Turner sendromu olarak, iki farklı tablo 


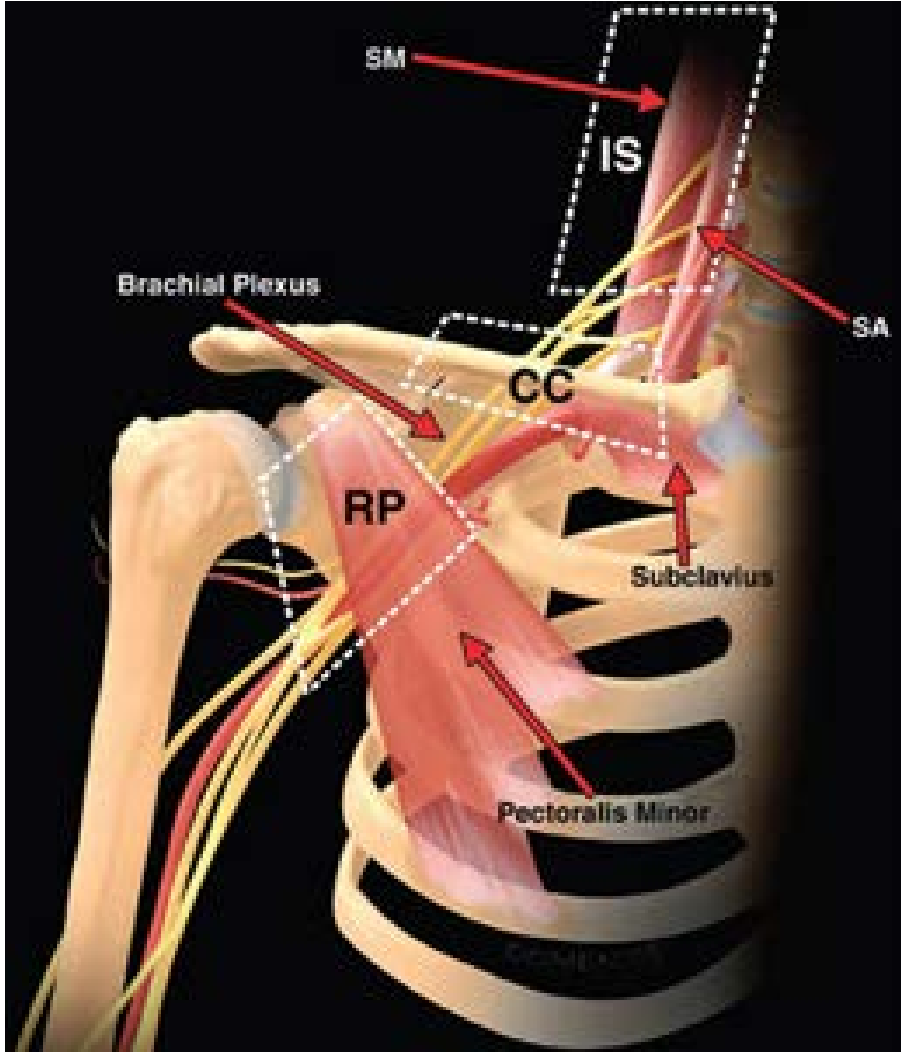

Şekil 18. Brakiyal pleksus üç boşlukta sıkışabilir (torasik outlet sendromu). Bunlar, interskalen mesafe (IS), kostaklaviküler mesafe (CC) ve retropektoral minör mesafedir (RP).

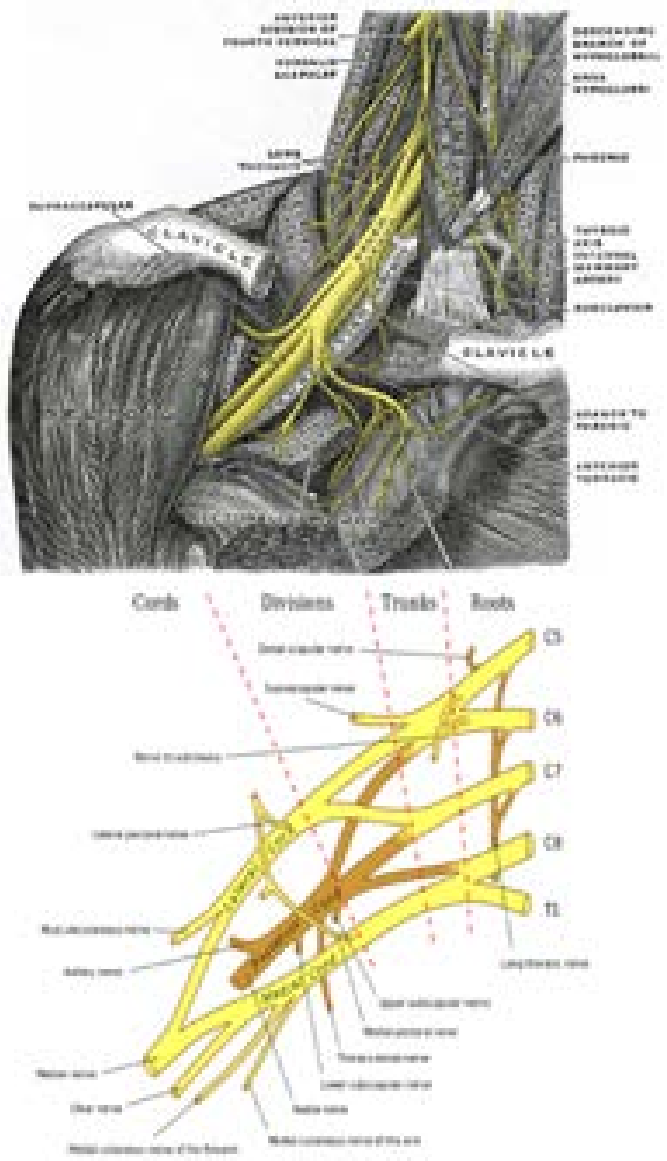

şeklinde ortaya çıkar. ${ }^{[23]}$ TOS, nörojenik ve/veya vasküler kökenli olabilir.

Nörojenik TOS'ta, brakiyal pleksus lifleri ile brakiyal arter-ven, interskalen-kostaklaviküler ve retropektoral minör mesafelerde sıkışabilir. TOS etmenleri arasında, skalen kaslarda travma sonrası gelişen fibrozis, klavikula fraktürleri sonrasında oluşan kallus formasyonları, servikal kosta, kas hipertrofileri ve kitleler (lipoma, nörojenik tümörler, aksesuvar kaslar, fibröz bantlar, pancoast tümörü) yer almaktadır. Sporcular arasında, halterciler, yüzücüler ve tenisçiler risk altında olan gruplardır (Şekil 19). ${ }^{[24]}$

Parsonage-Turner sendromu ise akut brakiyal nörit olup, etiyolojisi enfeksiyöz veya immünolojik kökenli olabilir. ${ }^{[25]}$

Konvansiyonel MR ve MR nörografi incelemelerinde, basıya neden olan patolojiler (fibrozis, kitle, servikal kot veya $C 7$ vertebra transvers çıkıntısında büyüme vb.) gösterilir. Brakiyal pleksus liflerinde kalınlaşma, hiperintensite ve kontrastlanma izlenirken, etkilenen kastaki ödem veya atrofi ortaya konur. ${ }^{[23]}$
Parsonage-Turner sendromunda etkilenen sinir, MR incelemede çoğunluka gösterilemez; ancak, denervasyona uğrayan kaslarda, STIR sekansında 2-4 gün içerisinde ödem ile uyumlu hiperintensite izlenir. Aylar içerisinde ise, kasta T1A sekanslarda yağlı atrofi gelişir. ${ }^{[26]}$ Torasik sinir, supraskapular sinir ve aksiller sinir, tek başına veya birlikte etkilenebilir. Supraskapular sinir çoğu olguda (\%97) tutulurken, aksiller sinir \%50 düzeyinde etkilenir. Subskapular sinir en az etkilenen sinirdir (\%3). Supraskapular sinir tutulduğunda, supraspinatus ve infraspinatus kasları, aksiller sinirde deltoid and teres minor kasları, subskapular sinirde subskapularis kas etkilenir. En sık supraspinatus kası etkilenirken, sıklık sırasına göre, infraspinatus, deltoid, teres minor ve subskapularis kasları tutulur. ${ }^{[23]}$

\section{Muskülokutanöz Sinir Nöropatisi}

Brakiyal pleksusun lateral kordundan köken alırken korakobrakiyalis, brakiyalis ve biseps kaslarını innerve eder. Sıklıkla korakobrakiyalis kası düzeyinde ve travma sonrasında sıkışır. ${ }^{[27]}$ 

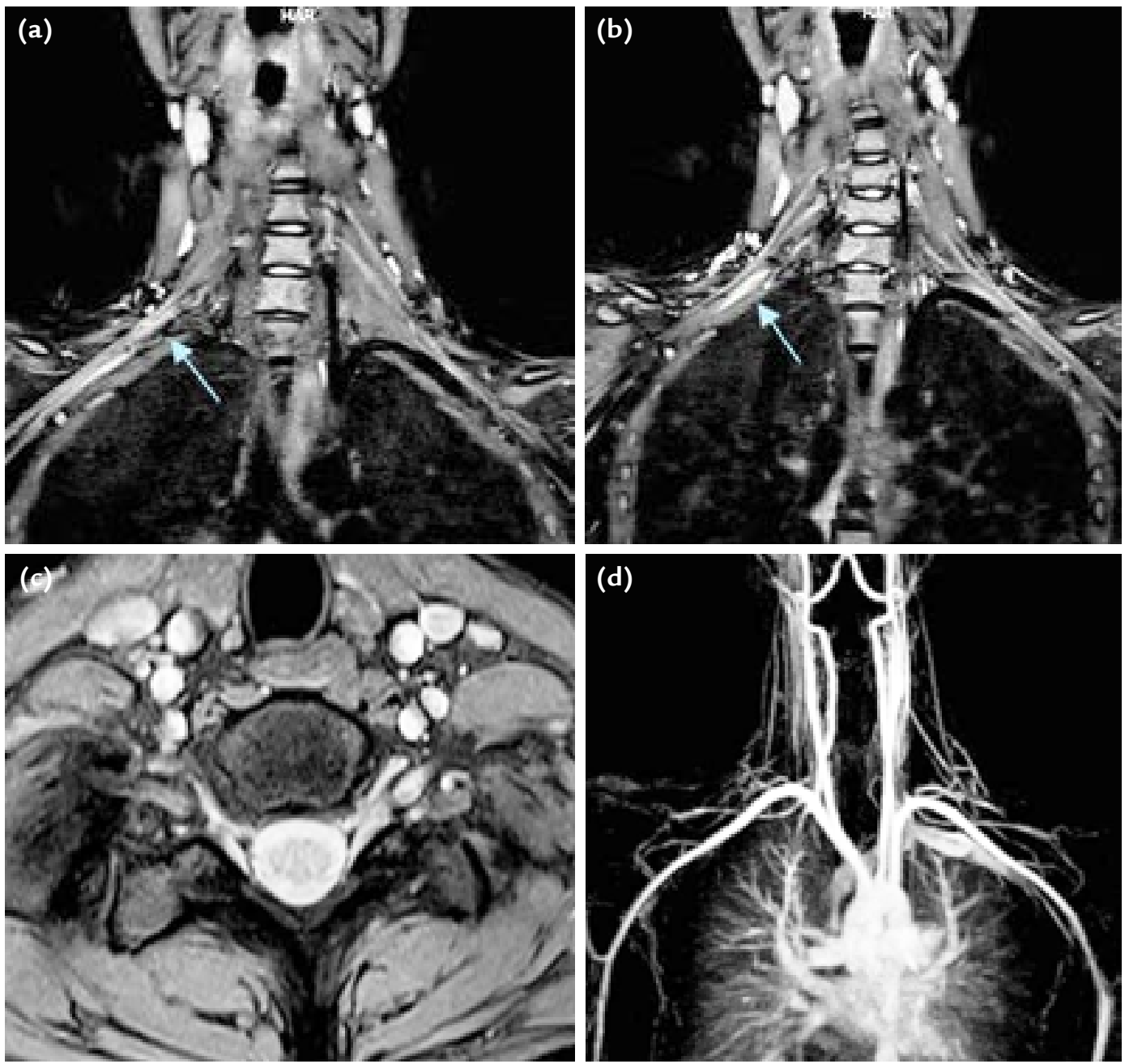

Şekil 19. a-d. Sağ brakiyal pleksopati-nörojenik TOS. STIR koronal (a, b) görüntülerde, skalen kasların sonrasında, sinir liflerinde kalınlaşma ve hiperintensite (ince ok) izleniyor. Cerrahi sonrası bu düzeyde fibrotik bant olduğu bildirilmiştir. Son görüntü (d) MR anjiyografi incelemesine ait olup, vasküler TOS ve üçüncü görüntüde (c) servikal diskopati dışlanmıştır.

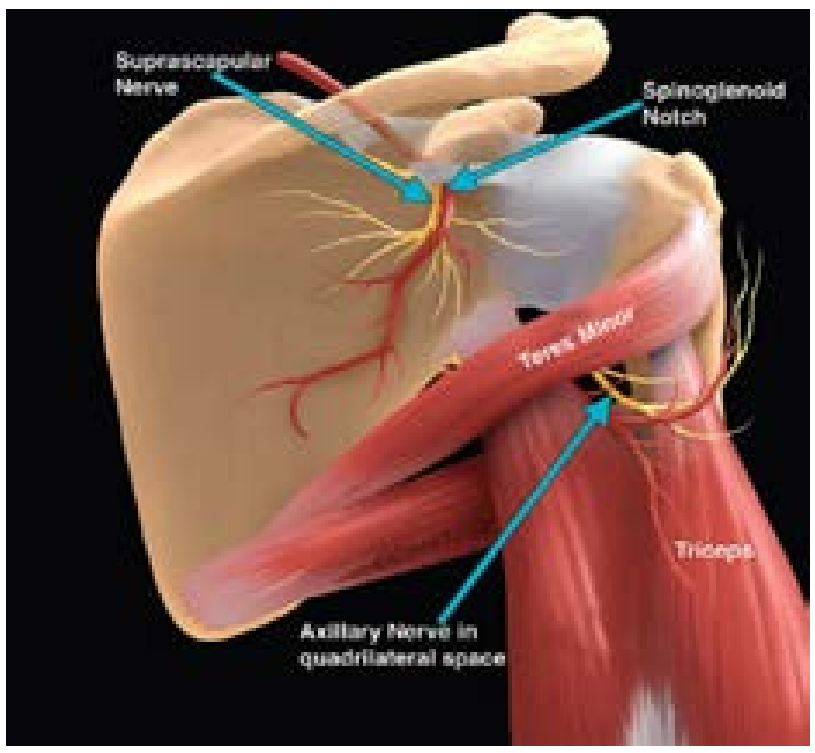

Şekil 20. Aksiller sinir ve kuadrilateral boşluk.

\section{Aksiller Sinir Nöropatisi}

Kuadrilateral boşluk, önde subskapular kas, arkada teres minör kası, mediyalde triseps kasının uzun başı ve lateralde humerus boynu arasında kalan boşluktur (Şekil 20). Omuz abduksiyon ve eksternal rotasyonda iken, posterior humeral sirkumfleks arter ve aksiller sinir sıkışır. Dinamik kompresyon yanı sıra, proksimal humerus ve skapula kırıklarında ve eşlik eden hematom varlığında, posteroinferior paralabral kist, teres minör kas hipertrofisinde, fibröz banda sekonder sıkışabilmektedir. Omuz ekleminin ileri evre osteoartriti, kal dokusu ve osteofitler bu siniri etkileyebilir.

MR incelemede, kuadrilateral boşluk, en iyi oblik koronal görüntülerde, aksiller sinir trasesi ise omuzun rutin oblik sagittal, koronal ve aksiyel görüntülerinde izlenmektedir. Sinir etrafında normal yağ planı 


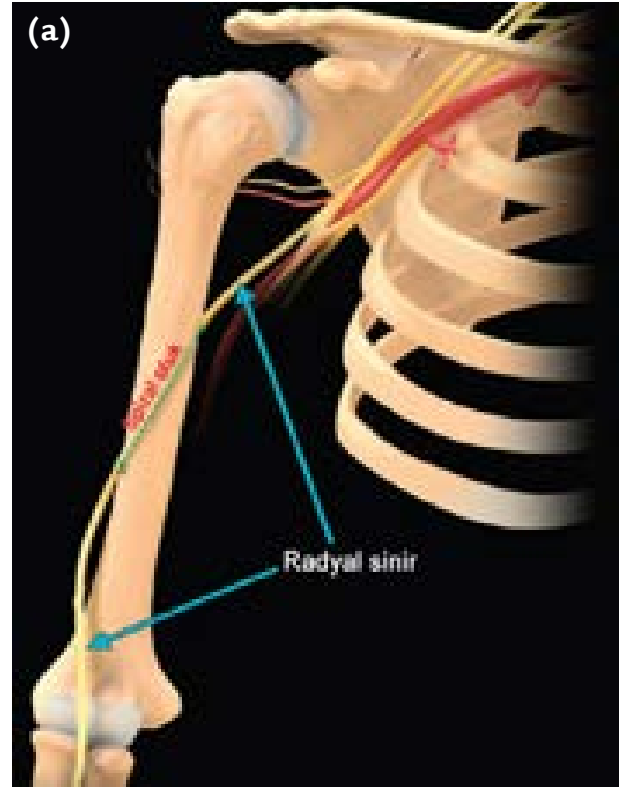

Şekil 21. a, b. Radyal sinir (a) ve dalları (b).

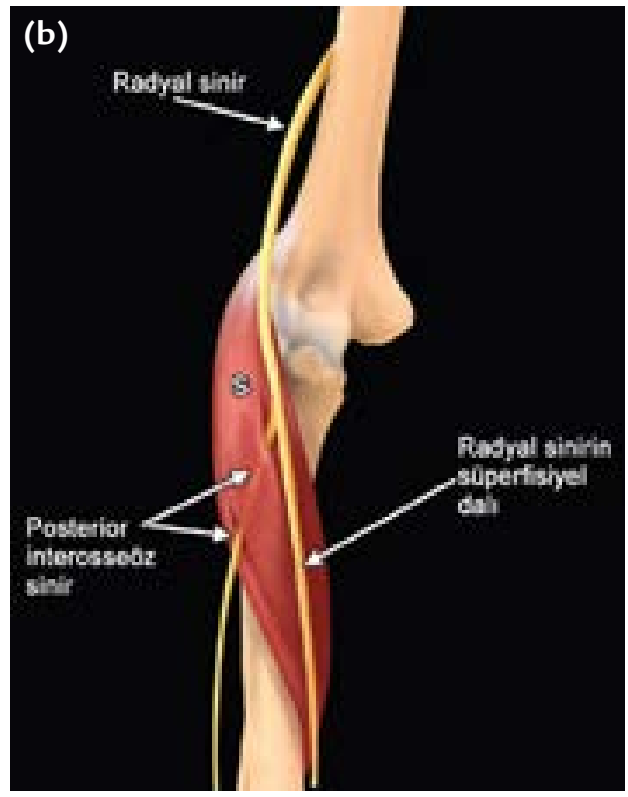

seçilmelidir ve kitle lezyonu olmamalıdır. Akut dönemde ödem izlenirken, subakut veya kronik aksiller sinir denervasyonunda, teres minör ile deltoid kas ödem ve atrofisi izlenmektedir. ${ }^{[28]}$

\section{Supraskapular Sinir Nöropatisi}

Supraskapular sinir, supraskapular çentik düzeyinde sıkışırsa, supraspinatus ve infraspinatus kasları birlikte etkilenir; spinoglenoid çentik düzeyinde sıkışırsa, sadece infraspinatus kası etkilenmektedir.

Supraskapular sinir sıkışması, skapula kırı̆g, omuz dislokasyonu, kitlelere bağlı omuz hareketi esnasında supraskapular bağ tarafindan kompresyon sonucu oluşmaktadır. Kitle, çoğunlukla gangliyon kisti iken, bu durum spinoglenoid çentikte daha fazla görülmektedir. Omuzda, kapsulolabral yaralanma sonucu gangliyon kistleri oluşabilir. Skapular çentikte kompresyona yol açacak bir neden yokken, supraspinatus ve infraspinatus kasları birlikte etkileniyorsa, ayırıcı tanıda Parsonage-Turner sendromu düşünülmelidir. [29] MR incelemede, basıya neden olan etken, sinir ve kasta oluşan patoloji ortaya konur.

\section{Radyal Sinir Nöropatisi (Şekil 21)}

Brakiyal pleksusun en geniş dalıdır. Triseps kasının mediyal ve lateral başları arasından, humerus diyafiz posteriorunda yer alan spiral olukta ilerler. Kolları uygun olmayan pozisyonda uyuyan insanlarda, spiral oluk sinir sıkışmasına meyil hazırlar (Cumartesi gecesi felci). Triseps ve brakiyoradyalis kasları, el ve el bileği ekstansör ve supinator kasları etkilenir. Radyal sinir, ayrıca humerus orta ve distal şaftı kırıklarında kemikle olan yakın ilişkisinden, lateral kas septumunu deldiği yerdeki azalmış hareketinden dolayı hasarlanabilir. Kemik parça, nörinoma, kırık fiksasyonu için kullanılan cihaza bağlı gerilme ve yassılaşma, kallus dokusu ve kitleler, siniri sıkıştırabilir.

Radyal sinirin en sık görülen tuzak nöropatisi, radyal tünel içinde olmaktadır. Radyal tünel, yaklaşık $5 \mathrm{~cm}$ uzunluğunda, içerisinde radyal sinirin uzandığı bir tüneldir. Radyal tünelin sınırını, posteriorda kapitellum, anterolateralde brakiyoradyalis ve ekstansör karpi radyalis brevis kasları oluşturmaktadır. Radyal tünelde sinir sıkışması, sinirin direkt kompresyona uğraması ile karakterizedir. Yüzücülerde ve koro şeflerinde, tekrarlayan pronasyon ve supinasyon hareketi de dinamik kompresyona yol açmaktadır. Mekanik kompresyon ise gangliyon kistine, lipom, vasküler malformasyon, sinovit, bisipitoradyal bursit, travmaya bağı şişme ve radius başı dislokasyonlarında gelişebilmektedir. Lateral epikondilit olgularında, bu sinirin derin dalı etkilenebilir. ${ }^{[30]}$

Radyal sinir, lateral epikondil distalinde ve supinator kas proksimalinde, yüzeyel ve posterior interosseöz (PIN) dallarına ayrılır. PIN, supinator kas düzeyinde yüzeyel ve derin dallarına ayrıldıktan sonra, Frohse arkadının derininden geçer. Bu siniri, yer kaplayan lezyonlar (solid-kistik), fibröz bantlar, travma ve izole nörit etkileyebilir. Ekstansör karpi radyalis brevis tendonu 

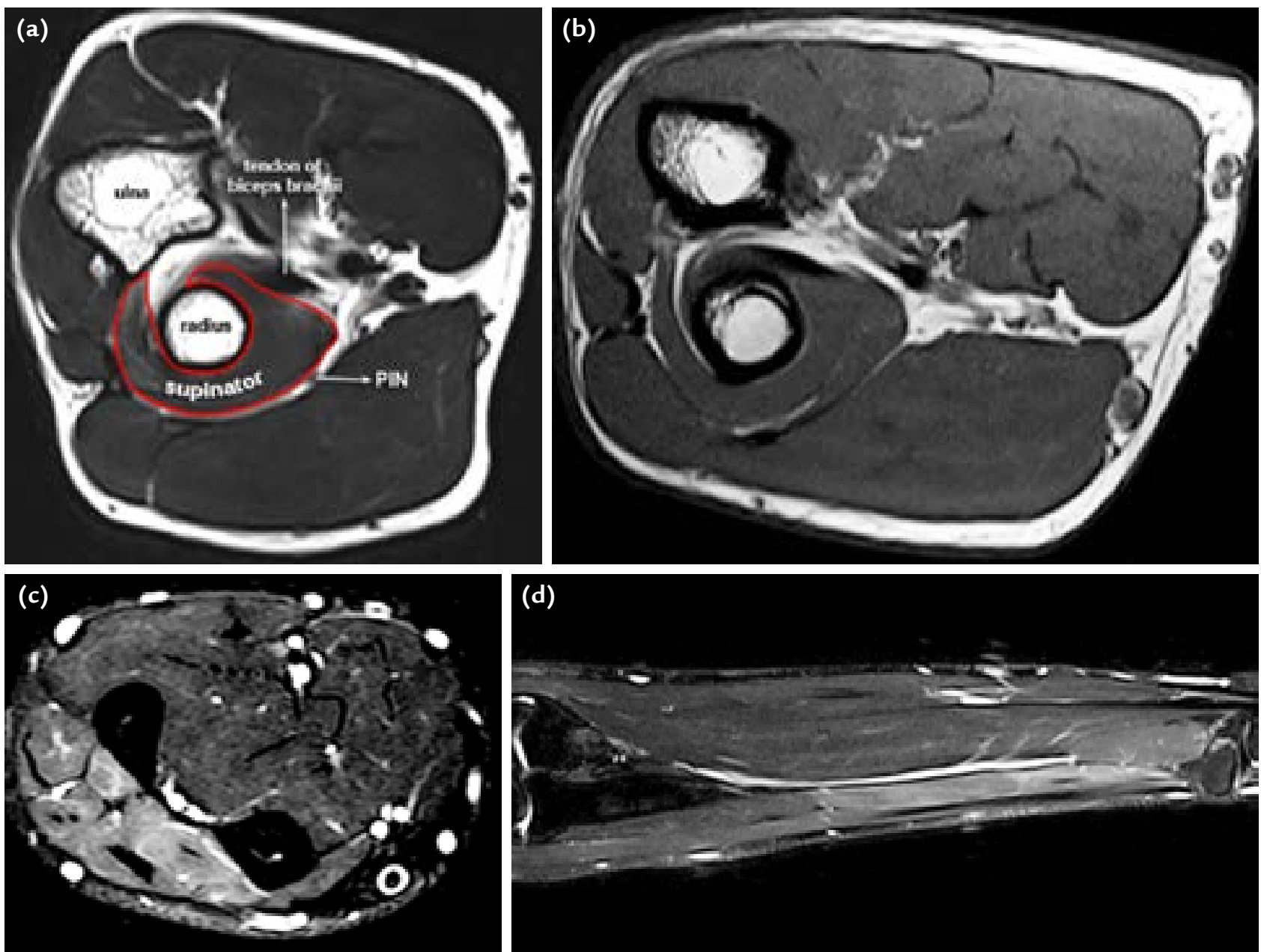

Şekil 22. a-d. Posterior interosseöz sinir sıkışması: İlk görüntü (T1A transvers) normal anatomiyi gösterirken (a), ikinci görüntüde supinator kasta hipertrofi izleniyor ve PIN çevresinde yer alan normal yağ doku planı silinmiştir (bası bulgusu) (b). STIR transvers (c) ve koronal (d) görüntülerde ise, etkilenen kasta subakut fazda denervasyon atrofisi ile uyumlu ödem-hiperintensite ve ılımlı atrofi izleniyor.

ve Froshe arkadında kalınlaşma, radyal arter patolojileri, bursit, sinovit ve nörojenik tümörler, nöropatiye neden olabilir. ${ }^{[30]}$

MR incelemede, radyal nöropatinin akut ve subakut evresinde, T2A-STIR sekanslarda etkilenen tüm kaslarda hiperintensite izlenir ve basıyı oluşturan neden görülebilir. Sinirde de benzer değişiklikler izlenirken, triseps, ekstansör karpi radyalis longus ve ankoneus kasları etkilenir (Şekil 22). ${ }^{31]}$

\section{Ulnar Sinir Nöropatisi (Şekil 23)}

Ulnar sinir, brakiyal pleksusun mediyal kordundan köken alır. Humerus orta bölümünde intermusküler septumu delerek, lateral epikondil düzeyine kadar posteromediyalde seyir gösterir. Ulnar sinirin mediyal epikondil öncesi $8 \mathrm{~cm}$ uzunluktaki segmenti, yaklaşık

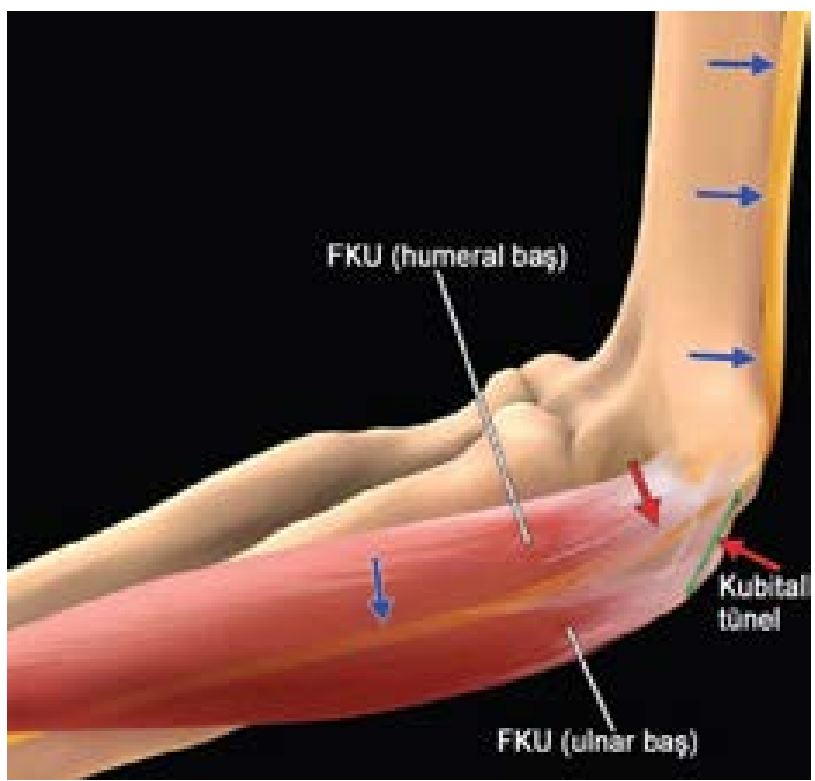

Şekil 23. Ulnar sinir ve kübital tünel. 

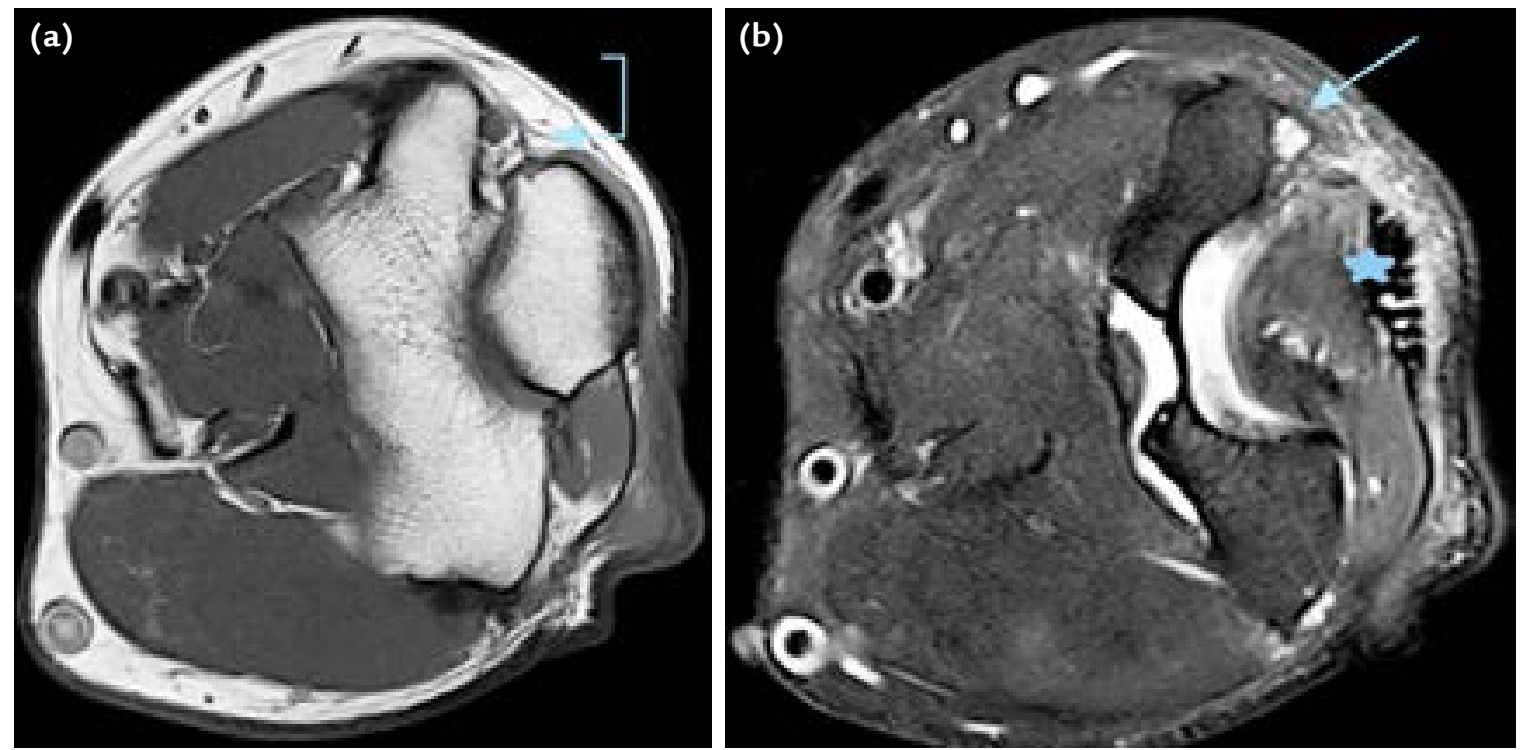

Şekil 24. a, b. Kübital tünel sendromu. T1A (a) ve STIR transvers (b) görüntülerde, kübital tünel retinakulumunda kalınlaşma (açılı ok) izlenirken, tünelde yer alan ulnar sinirde (düz ok) kalınlaşma ve nöritis ile uyumlu hiperintensite dikkati çekmektedir. Ayrıca triseps tendiniti (yıldız) ve çevresel ödem-hiperemi gözleniyor.

\%70 olguda, Struthers arkadı altından geçer. Ulnar sinir, humerus mediyal epikondili ile olekranon arasında kondiller oluktan, kübital tünel retinakulumu (KTR) ve fleksör karpi ulnaris (FKU) iki başının arasında oluşan aponöroz derininden geçmektedir. Ulnar sinir, KTR altında veya yanında sıkışabilir ve buna kübital tünel sendromu adı verilir. Ulnar sinir pozisyonu, tünel içinde dirseğin pozisyonlarına göre değişebilmektedir. Dirsek fleksiyonda iken, KTR ile humerus mediyal epikondili arasında sıkışabilir veya KTR kenarından disloke olabilir. Kübital tünel sendromu, ulnar sinir subluksasyon veya dislokasyonuna, aksesuvar epitroklear-ankoneus kası, gangliyon kisti, ulnar sinirin KT içinde valgus deformitesi sonucunda sıkışmasına ve arkuat bağretinakulumdaki kalınlaşmaya bağlı gelişebilir. Ayrıca, sıkışma, mediyal intermusküler septum ve Struthers arkadı arasında olabilir. Bunun yanında, direkt travma, osteofit, sinovit, solid kitleler, unlar kollateral bağ patolojileri, kubitus valgus ve varus deformiteleri, etmenler arasında yer alır. ${ }^{[32-34]}$

MR incelemelerinde, unlar sinir, T1A sekanslarda kas ile izointens izlenirken, T2A ve STIR sekanslarda hafif hiperintens olarak karşımıza çıkar. Sıkışma ile, sinirde kalınlaşma ve STIR sekanslarda artmış hiperintensite izlenirken, önemli bir bulgu olan, sinirde fasiküler bozulma gelişir. Sıkışmaya neden olan etmenler gözlenirken, yine tüm tuzak nöropatilerde olduğu gibi, denervasyona uğrayan kol kaslarında akut ve kronik evreye göre patolojik bulgular ortaya çıkar (Şekil 24). [35]

\section{Median Sinir ve Anterior İnterosseöz Sinir Nöropatisi}

Median sinir, brakiyal pleksusun mediyal ve lateral kordlarından köken alır. Median sinir, en fazla karpal tünelde sıkışırken, önkol proksimalinde ve kol distalinde de olabilmektedir. En sık basıya maruz kalınan bölgeler; suprakondilar spur, Struthers bağı, bisipital aponevroz, pronator teres kası boyunca ve fleksör dijitorum süperfisiyalis kasının fibröz arkıdır (Şekil 25).

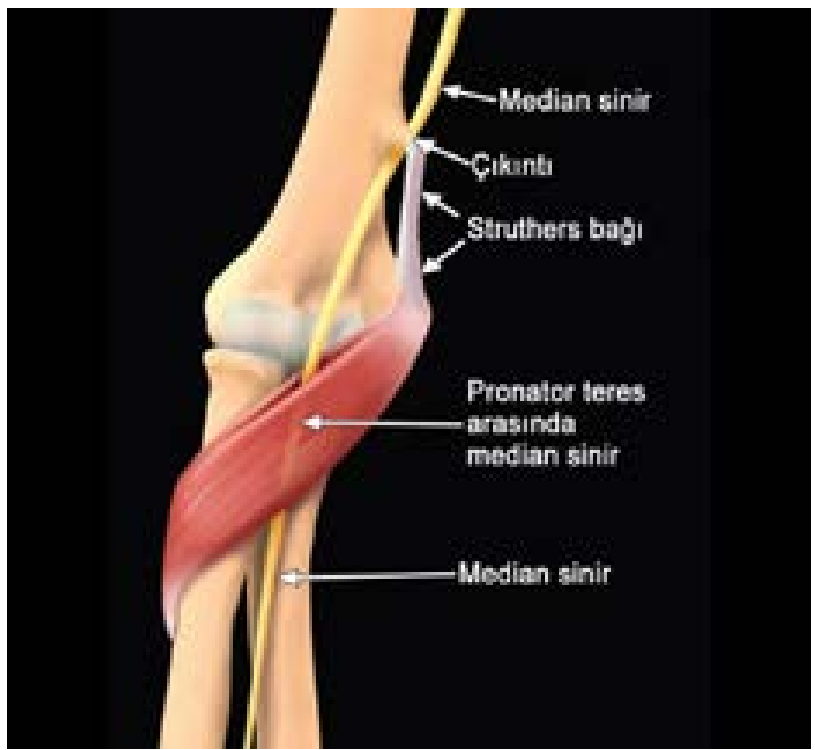

Şekil 25. Median sinir. 
Median sinir, suprakondiller fraktür, dirsek dislokasyonu, enjeksiyon yaralanmaları ve pronator sendromu sonucunda sıkışabilir. Pronator sendromu, sinirin pronator teres kasının iki başı arasındaki mesafede sıkışması sonucunda oluşur. Bu düzeyde, kalınlaşmış bisipital aponöroz, hipertrofik kas, aberan median arter, radyal arterde çaprazlaşma veya kitleler bası oluşturabilir. MR incelemede, median sinirde oluşan kalınlaşma ve hiperintensite izlenebilirken, yukarıda sayılan etmenler ortaya çıkarılır. Denervasyona uğrayan kaslarda ise, hastalık evresine göre, ödem veya atrofi izlenir. ${ }^{[36]}$

Anterior interosseöz sinirin sıkışması ise, Kiloh-Nevin sendromu olarak bilinir. Bu sinir, median sinirin geniş dalıdır ve sadece motor innervasyon sağlar. Humerus mediyal epikondilinin yaklaşık 5-8 cm distalinden çıkmaktadır. Önkol ve suprakondiller kırıklarda, yanlış alçılama, kolun üstüne yatarken basınç, yük kaldırma ve viral nöritler, kitleler, bisipital bursit, varisler, aksesuvar kas (Gantzer kası) ve vasküler anomaliler sonucu sinir sıkışması oluşabilmektedir. ${ }^{[37]}$

\section{Karpal Tünel Sendromu}

Karpal kemikler ve fleksör retinakulum arasında kalan bir boşluktur. Bu boşluk, yaklaşık $6 \mathrm{~cm}$ uzunluğundadır ve bilekten el ayası orta kesimine kadar uzanır. Bu boşluktan, median sinirin yanı sıra, sekiz tane fleksör dijitorum profundus (FDP) ve süperfisiyalis (FDS), bir fleksör pollisis longus tendonu geçer. Fleksör retinakulum, skafoid tüberositazına, radyal tarafta trapezyumun tepesine, unlar tarafta pisiform ve hamat kemiklerin kancasına bağlanır. Radyal tarafta, fleksör karpi tendonunu sarmak için iki kata ayrilır. Median sinir, karpal tünel proksimalinde FDS yüzeyelinde, karpal tünel içinde 2. ve 3. FDS kasa paralel uzanır. EI ayasında beş dal verir; radyal dal, tenar kasları innerve

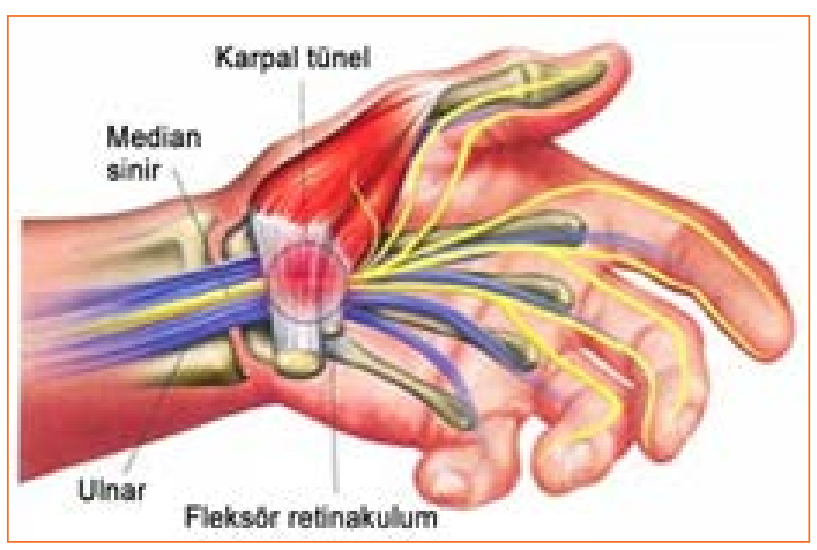

Şekil 26. Karpal tünel ve median sinir.

eden motor sinirdir; geri kalan dört dal, 1.-3. parmakların ve 4. parmağın radyal yarısının duysal innervasyonunu sağlayan sinirlerdir. Karpal tünel daraldığında, gereksiz doku, iskemik değişiklikler, perinöral ve epinöral ödeme yol açar. İskemi uzadıkça, ödem yerini fibrozise bırakır (Şekil 26). ${ }^{[38]}$

Üst ekstremitenin en sık karşımıza çıkan tuzak nöropatisi olup, orta yaş kadın hastalarda sıktır. Diyabet, romatoid artrit, gut, kalsiyum pirofosfat depolanması, amiloid depolanması, akromegali, gebelik, hipotiroidizm, kitleler (gangliyon kisti, lipom vb.), spur ve kırıklar, fleksör retinakulumda kalınlaşma, travma veya cerrahi sonrasında oluşan skar doku gelişimi, önemli etmenlerdir (Şekil 27). ${ }^{38]}$

Karpal tünel sendromunda; tanıda şüphe ve ikinci bir patoloji olasılığı varsa, bulgular atipik ise ve olgu daha önce operasyon geçirmiş ise, görüntülemeye ihtiyaç duyulur. MR ve MR nörografide, median sinir, karpal tünel trasesi boyunca görüntülenmelidir. Akut
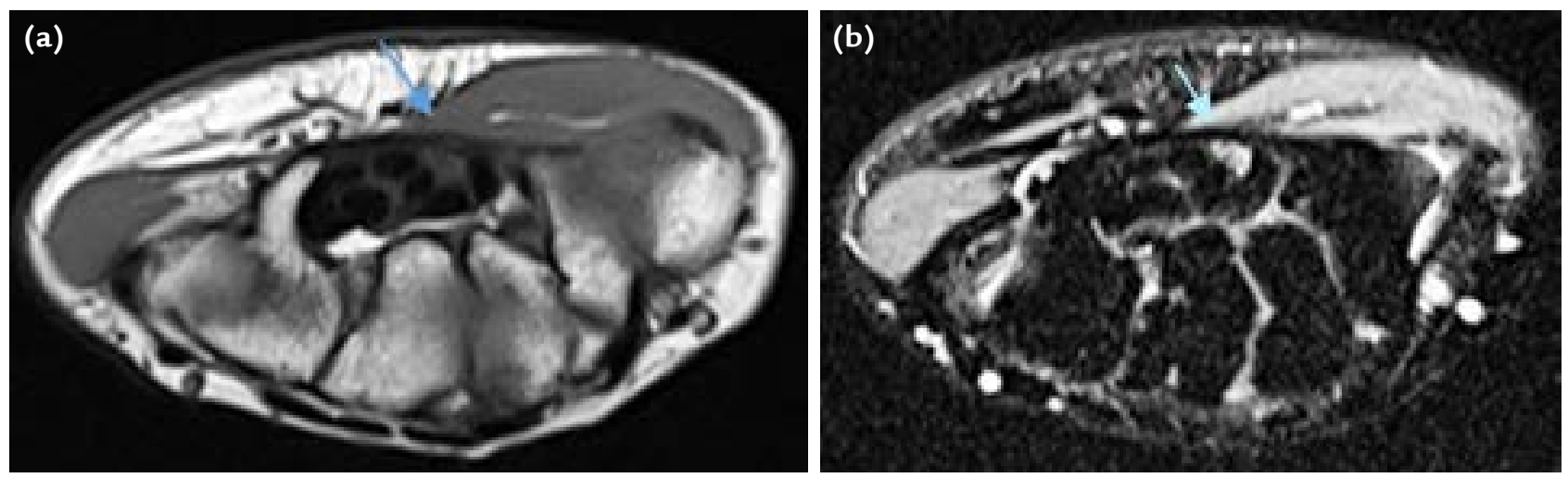

Şekil 27. a, b. Ayırıcı tanı için yapılan MR incelemede, karpal tünel düzeyinde, median sinir T1A transvers (a) görüntüde kas ile izointens izlenirken, T2 yağ baskılı sekansta hiperintens sinyal özelliğinde ve normal kalibrasyonda izlenmektedir (b). 
dönemde, median sinirde kalınlaşma ve hiperintensite izlenirken, kronik dönemde sinirin normal intensitesi azalabilir. Normal median sinir, pisiform kemik düzeyinde yassı olup, kalınlaşma genelde pisiform kemik düzeyinde değerlendirilir. Hamat kemik düzeyinde ise, retinakulumun kalınlaştığı olgularda, sinirdeki patolojik yassılaşma izlenebilir. Yer kaplayan kitleler, sinirin kendi tümörleri (nörinoma, fibrolipomatöz hamarto$\mathrm{ma}, \mathrm{vb}$.) ve diğer etmenler kolaylıkla tespit edilir. Distal kesimde, etkilenen kaslarda akut ve kronik evrede oluşan denervasyona bağlı değişiklikler izlenebilir. ${ }^{[39,40]}$ Tümör ve enfeksiyon durumları ile romatoid artrit gibi inflamasyon düşünülen olgularda, MR inceleme, kontrastlı çekimlerle tamamlanmalıdır (Şekil 28, 29).

\section{Guyon Kanalı}

Ulnar sinir, el bileğinde Guyon kanalı olarak bilinen fibroosseöz bir tünelden geçer (Şekil 30). Bu tünel, pisiform kemiğin proksimal kenarındaki volar karpal bağdan, hamulus düzeyinde hipotenar kas kökeni arasında uzanır ve yaklaşık $4 \mathrm{~cm}$ uzunluğundadır. Tünelin tabanını, pisiform ve hamat kemik ile fleksör retinakulum ve hipotenar kaslar, çatısını ise volar karpal bağ, palmaris brevis kası ve palmar faysa lifleri oluşturur.
Ulnar arter ve sinir ile birleştirici venler, bu tünelden geçer ve yağla çevrilidir. Ulnar sinirin motor dalı palmaris brevisi, hipotenar kas, lateral lumbrikal ve interosseöz kas, adduktor pollisis, abduktor dijiti minimi kaslarını innerve eder. Gangliyon kisti, lipoma gibi yer kaplayan lezyonlar, travma, anormal madde birikimi, aberran kasların kanal içine uzanması gibi anatomik kas varyasyonları, sinirin sıkışmasında etkilidir. Anevrizma, tekrarlayan travmalara bağlı unlar arter trombozu gibi vasküler anormallikler ve kal doku - hamat fraktürleri de basıya neden olmaktadır.

MR incelemelerde, Guyon kanalı, içerisinde unlar sinir yuvarlak veya oval, normal intensitede ve çevresinde yağ doku olacak şekilde izlenir ve ortalama kalınlığı 3 mm'dir. MR ve MR nörografi incelemeleri, Guyon kanalı ve çevresinde olabilecek yer kaplayan kitle ve diğer etmenleri, sinirdeki kalınlaşma ve hiperintensiteyi, denervasyona uğrayan kaslardaki değişiklikleri gösterir. ${ }^{[38]}$

\section{Median Sinirin Palmar Kutanöz Dalı}

Bu sinir, distal ön kolda median sinirin radyal tarafta yer alan dalıdır, palmaris longus ve fleksör karpi radyalis tendonları arasında yer alır (Şekil 31). ${ }^{[41]}$
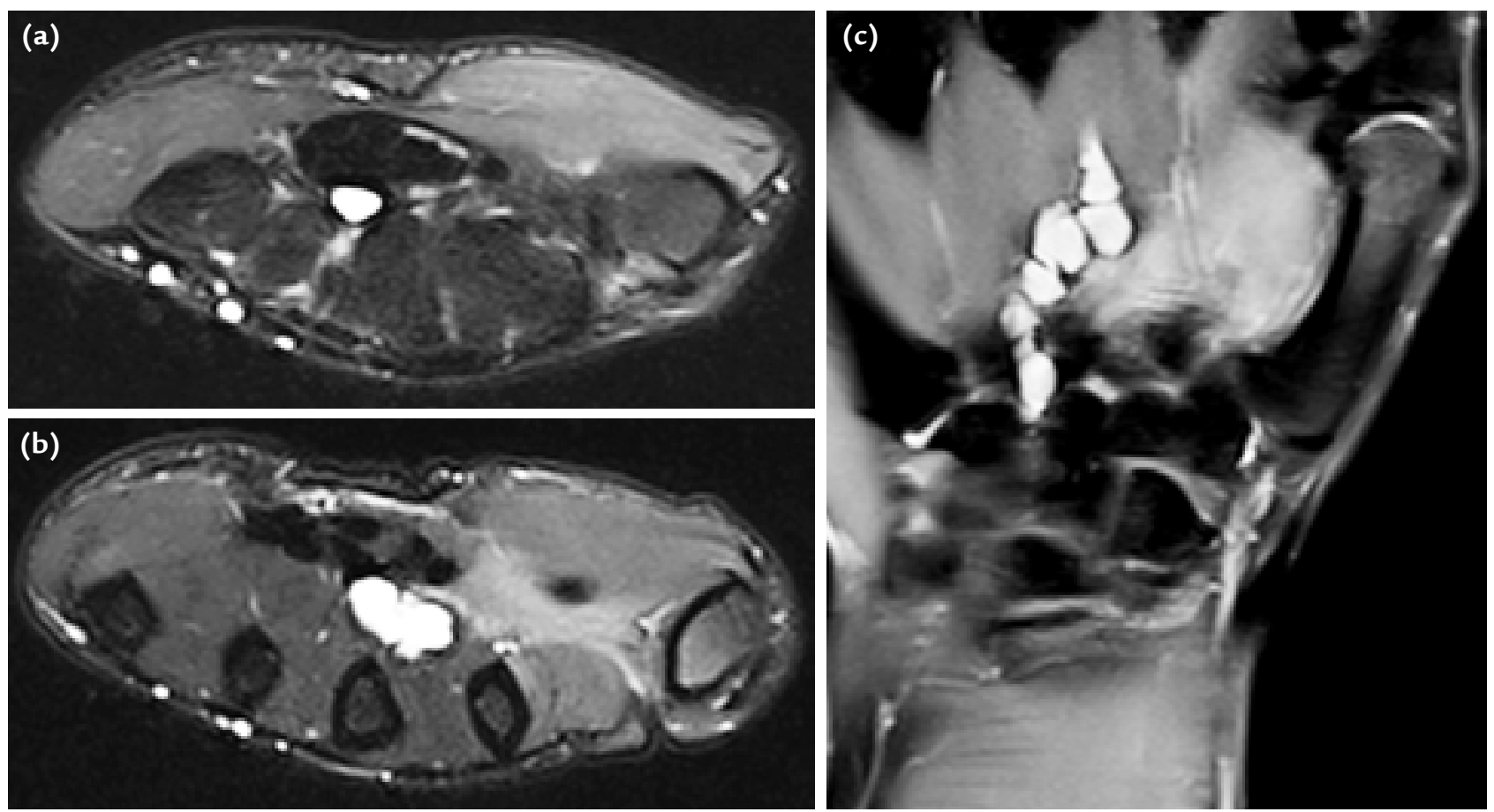

Şekil 28. a-c. Karpal tünelin distal kesminden başlayan ve el orta bölümüne kadar devam eden, fleksör tendonların palmar tarafında yer alarak, indirekt olarak median sinire bası oluşturan, sıvı intensitesinde gangliyon kisti izleniyor. Basıya bağlı olarak tenar tarafta ilgili kaslarda denervasyona sekonder gelişen ödem ile uyumlu hiperintensite izlenmektedir. Illk iki görüntü STIR transvers (a, b), son görüntü STIR koronal sekanstır (c). 

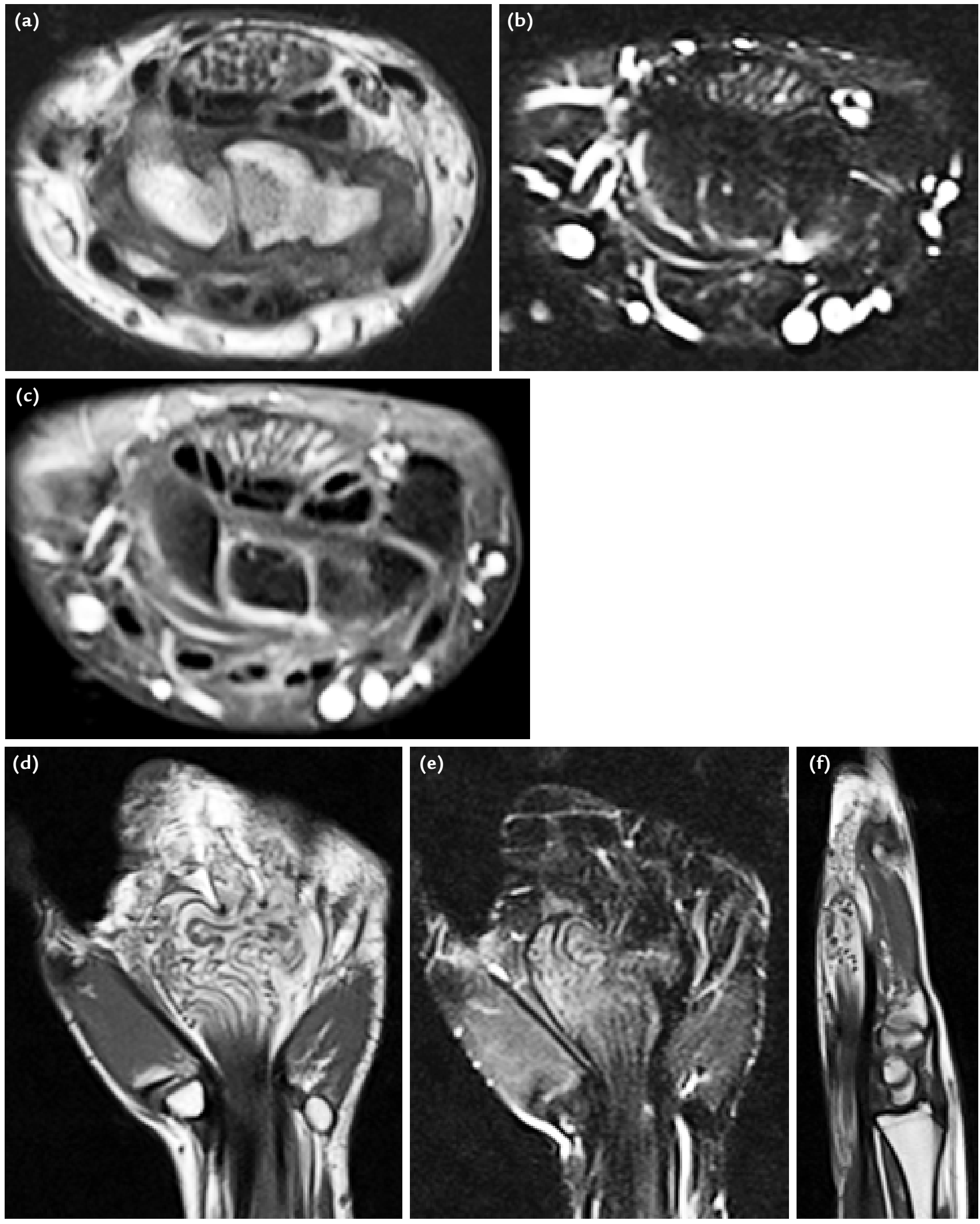

Şekil 29. a-f. Median sinirde fibrolipomatöz hamartoma. Karpal tünelden başlayan ve el ayasında median sinir trasesinde distale doğru devam eden, fuziform, yağ içeren, IVKM sonrasında kalınlaşmış sinir fasiküllerinde, kontrastlanma gösteren kitle izlenmektedir (a, T1A transvers; b, STIR transvers; c, kontrast sonrası T1A yağ baskılı transvers; d, T1A koronal; e, STIR koronal; f, T1A sagittal). 

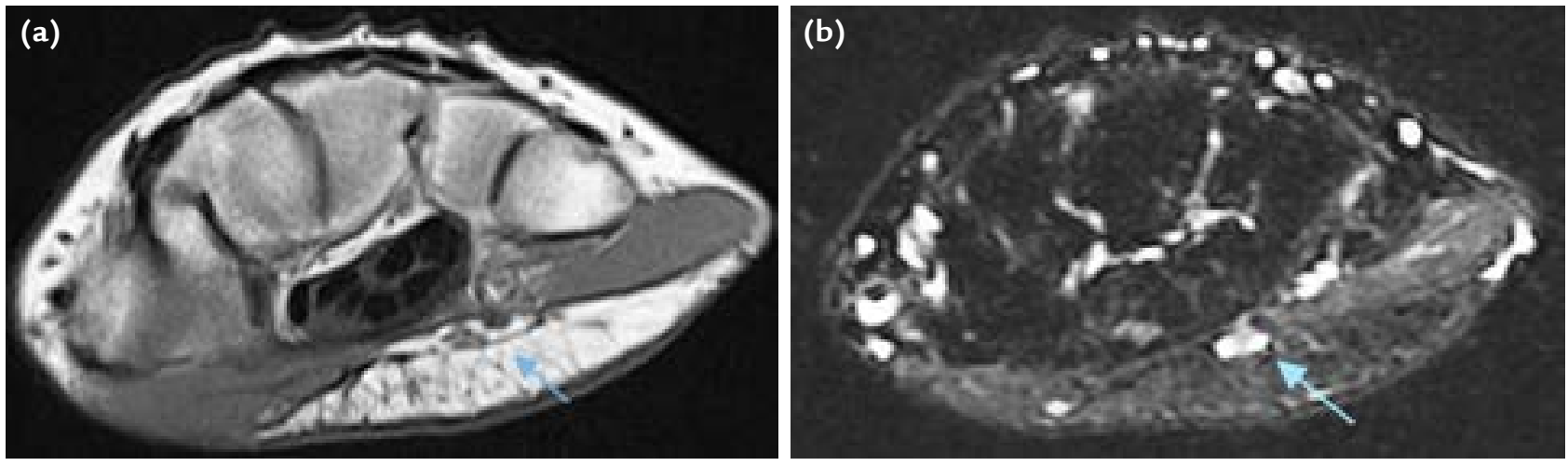

Şekil 30. a, b. Normal Guyon kanalı: T1A transvers (a) ve STIR transvers (b) görüntülerde, kanal içerisinde ulnar sinir ve vasküler yapılar izlenmektedir.

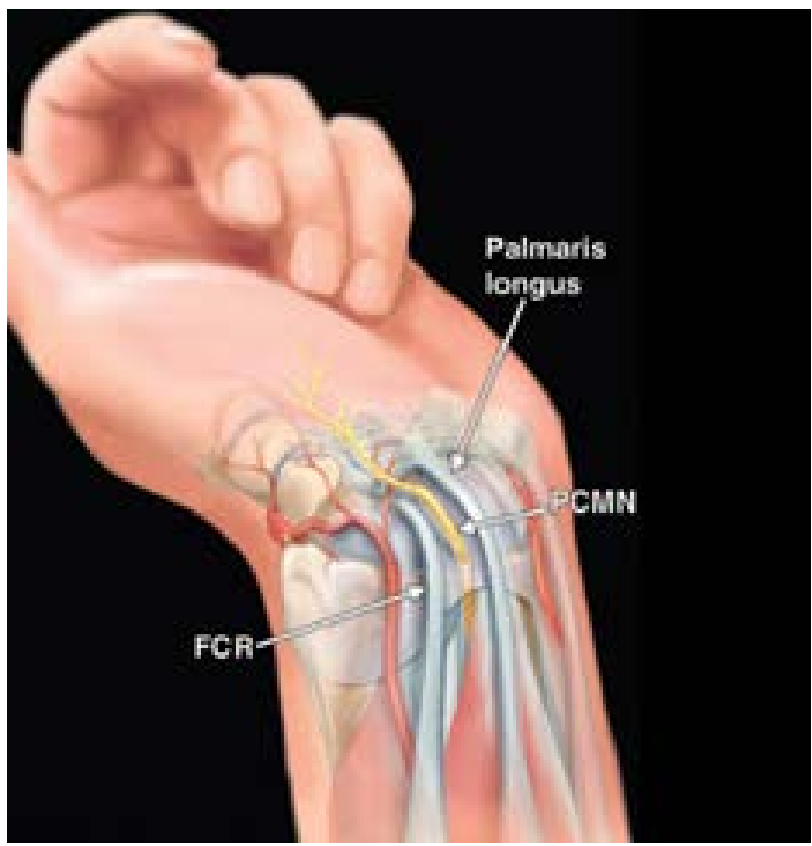

Şekil 31. Palmar kutenöz sinir.

Fleksör karpi radyalis tendon gangliyon kistleri, kalınlaşmış antebrakiyal faysa, atipik palmaris longus kası, direkt travma ve geçirilmiş travmatik bölgesel cerrahiler, bu siniri sıkıştırabilir. ${ }^{[41]}$

\section{Radyal Sinirin Yüzeyel Dalı (Şekil 32)}

Önkolun distal radyal tarafinda yüzeyel yerleşimli olup, radyal arter, ekstansör retinakulum, ekstansör pollisis brevis ve abduktor pollisis longus tendonları ile komşuluk gösterir. De Qeurvain hastalığında (stenozan tenosinovit), bu sinir sıklıkla etkilenir. MR incelemede, ilgili tendonlarda kalınlaşma ve hiperintensite ile birlikte, tendon kılıfında sıvı artışının yanı sıra, sinirde kalınlaşma ve hiperintensite izlenir (Şekil 33). ${ }^{[42]}$

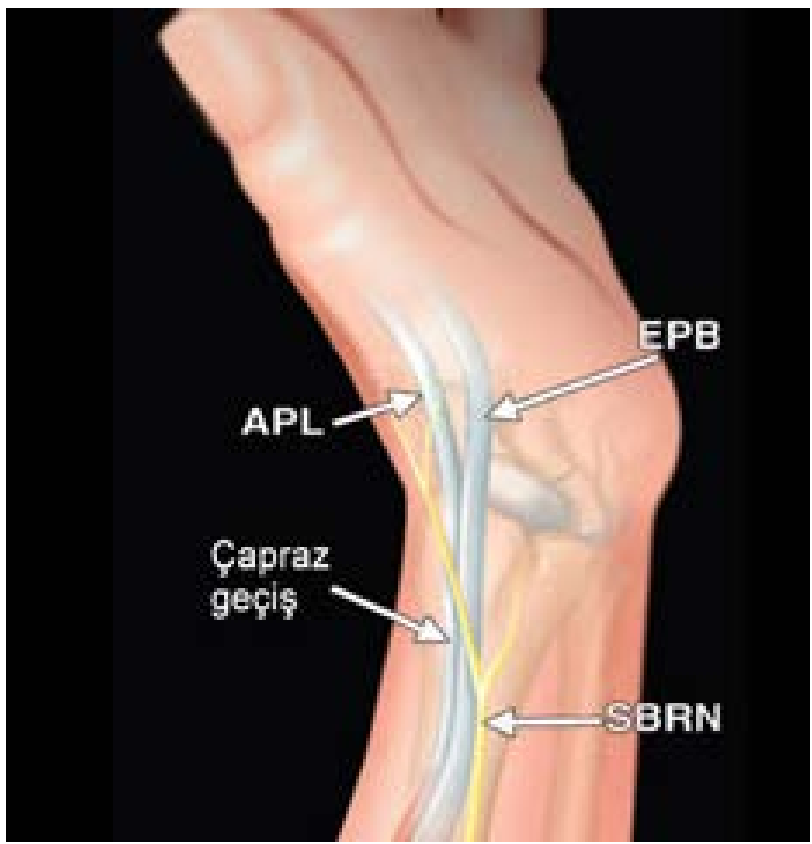

Şekil 32. Radyal sinirin yüzeyel dalı.

\section{SONUÇ}

Tuzak nöropatilerinin tanısı, çoğunlukla klinik muayene ve elektrofizyolojik çalışmalar ile konur. MR incelemeleri, etkilenen sinirde ve kaslarda oluşan değişiklikleri, ilgili anatomik bölgenin normal yapıları ile yer kaplayan lezyonları ortaya koyar; hastalığın akut, subakut ve kronik evrelerini belirleyebilir. Tanı ve ayırıcı tanı yanı sıra, takip ve tedavinin seçiminde kullanılır. Seçilmiş olgularda yapılacak MR nörografi incelemesi ve kontrastlı çalışmalar, özgüllük ve duyarlılığı arttırır. Klinik kullanımı giderek artan, yüksek Tesla gücüne ve çözünürlüğe sahip yeni nesil MR cihazları ile yapılacak çalışmalar, tuzak nöropatilerde daha büyük rol oynayacaktır. 

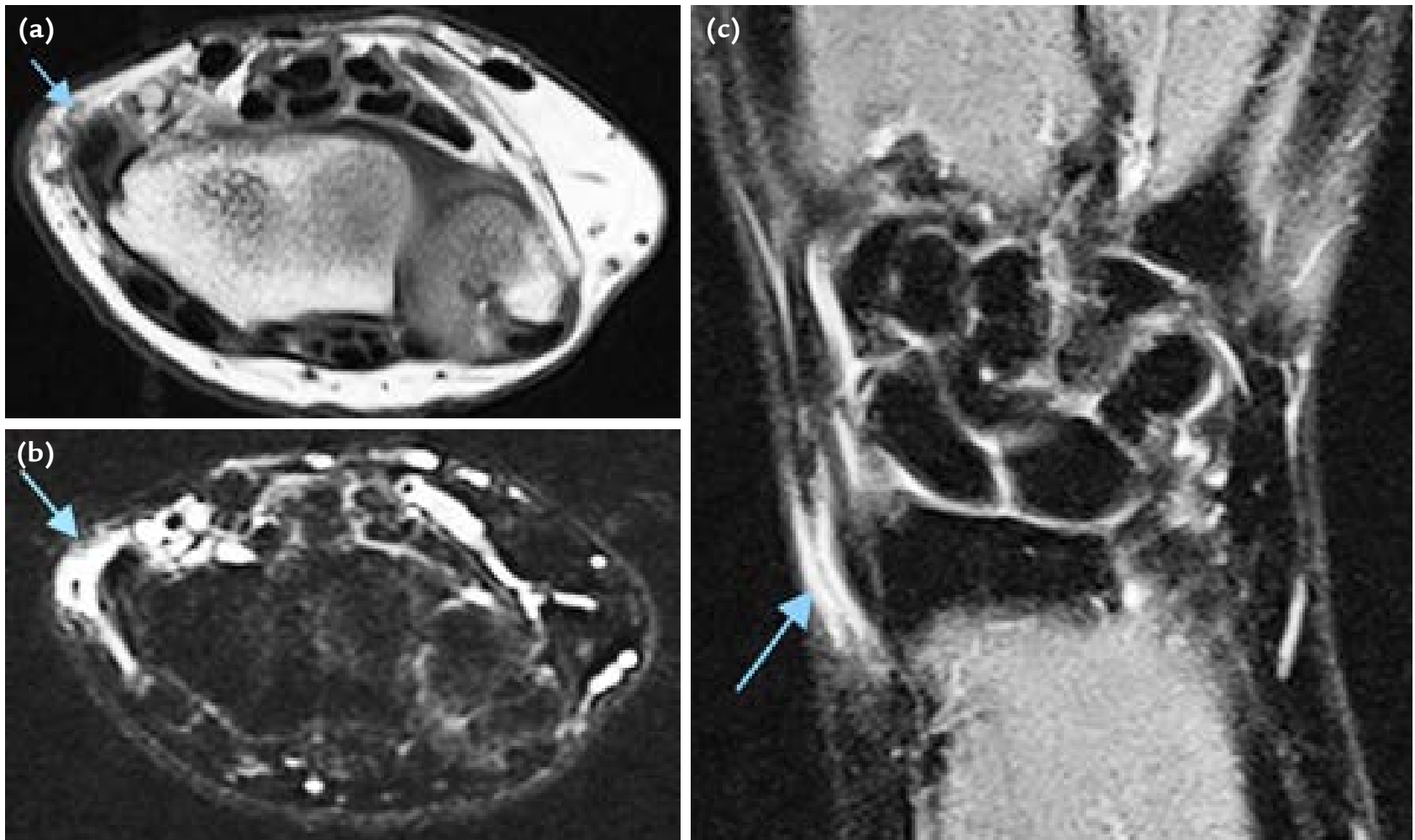

Şekil 33. a-c. De Quervain sendromu. T1A transvers (a), STIR transvers (b) ve STIR koronal (c) görüntülerde, el bileği radyal tarafinda ekstansör pollisis brevis ve abduktor pollisis longus tendonlarında kalınlaşma, sinyal artışı ve çevre yumuşak dokuda inflamatuvar ödem izlenmektedir.

\section{KAYNAKLAR}

1. Oh SJ. Clinical Electromyography: Nevre Conduction Studies, 2nd ed. Philadelphia: Lippincott Williams \& Wilkins; 2003.

2. Petchprapa CN, Rosenberg ZS, Sconfienza LM, Cavalcanti CF, Vieira RL, Zember JS. MR imaging of entrapment neuropathies of the lower extremity. Part 1. The pelvis and hip. Radiographics 2010;30(4):983-1000. CrossRef

3. Donovan A, Rosenberg ZS, Cavalcanti CF. MR imaging of entrapment neuropathies of the lower extremity. Part 2. The knee, leg, ankle, and foot. Radiographics 2010;30(4):100119. CrossRef

4. Russell JM, Kransdorf MJ, Bancroft LW, Peterson JJ, Berquist TH, Bridges MD. Magnetic resonance imaging of the sacral plexus and piriformis muscles. Skeletal Radiol 2008;37(8):709-13. CrossRef

5. Agar M, Broadbent A, Chye R. The management of malignant psoas syndrome: case reports and literature review. J Pain Symptom Manage 2004;28(3):282-93.

6. Torriani M, Souto SC, Thomas BJ, Ouellette H, Bredella MA. Ischiofemoral impingement syndrome: an entity with hip pain and abnormalities of the quadratus femoris muscle. AJR Am J Roentgenol 2009;193(1):186-90. CrossRef

7. Stewart JD. Compression and entrapment neuropathies. In: Dyck PJ, Thomas PK, Griffin JW, Low PA, Poduslo JF, editors. Peripheral Neuropathy, 3rd ed. Philadelphia: Saunders; 1993. p.961-79.
8. Pirouzmand F, Midha R. Subacute femoral compressive neuropathy from iliacus compartment hematoma. Can J Neurol Sci 2001;28(2):155-8.

9. Harney D, Patijn J. Meralgia paresthetica: diagnosis and management strategies. Pain Med 2007;8(8):669-77.

10. Bradshaw C, McCrory P, Bell S, Brukner P. Obturator nerve entrapment. A cause of groin pain in athletes. Am J Sports Med 1997;25(3):402-8.

11. Yuen EC, So YT. Sciatic neuropathy. Neurol Clin 1999;17(3):617-31.

12. Leno $C$, Combarros $O$, Polo JM, Rebollo M, Berciano J. Bilateral obturator neuralgia secondary to osteitis of the pubis. Arch Neurobiol (Madr) 1984;47(6):347-52.

13. Pecina $\mathrm{HI}$, Boric I, Smoljanovic $\mathrm{T}$, Duvancic $\mathrm{D}$, Pecina M. Surgical evaluation of magnetic resonance imaging findings in piriformis muscle syndrome. Skeletal Radiol 2008;37(11):1019-23. CrossRef

14. Thoma A, Levis C. Compression neuropathies of the lower extremity. Clin Plast Surg 2003;30(2):189-201.

15. Filler AG, Haynes J, Jordan SE, Prager J, Villablanca JP, Farahani K, McBride DQ, Tsuruda JS, Morisoli B, Batzdorf $U$, Johnson JP. Sciatica of nondisc origin and piriformis syndrome: diagnosis by magnetic resonance neurography and interventional magnetic resonance imaging with outcome study of resulting treatment. J Neurosurg Spine 2005;2(2):99-115. 
16. Hollis $\mathrm{MH}$, Lemay $\mathrm{DE}$, Jensen MP. Nevre entrapment syndrome of the lower extremity. http://emedicine.medscape. com/article/1234809

17. Edwards PH Jr, Wright ML, Hartman JF. A practical approach for the differential diagnosis of chronic leg pain in the athlete. Am J Sports Med 2005;33(8):1241-9.

18. Kennedy JG, Baxter DE. Nerve disorders in dancers. Clin Sports Med 2008;27(2):329-34. CrossRef

19. Labib SA, Gould JS, Rodriguez-del-Rio FA, Lyman S. Heel pain triad: the combination of plantar fasciitis, posterior tibial tendon dysfunction and tansal tunnel syndrome. Foot Ankle Int 2002;23(3):212-20.

20. Schon L. Chronic pain. In: Myerson M, editor. Foot and Ankle Disorders, vol 2. Philadelphia, PA: Saunders; 2000. p.851-81.

21. Kim JY, Choi JH, Park J, Wang J, Lee I. An anatomical study of Morton's interdigital neuroma: the relationship between the occurring site and deep transverse metatarsal ligament (DTML). Foot Ankle Int 2007;28(9):1007-10.

22. Andreisek G, Burg D, Studer A, Weishaupt D. Upper extremity peripheral neuropathies: role and impact of MR imaging on patient management. Eur Radiol 2008;18(9):1953-61. CrossRef

23. Demondion $X$, Herbinet $P$, Van Sint Jan $S$, Boutry $N$, Chantelot C, Cotten A. Imaging assessment of thoracic outlet syndrome. Radiographics 2006;26(6):1735-50.

24. Linda DD, Harish S, Stewart BG, Finlay K, Parasu N, Rebello RP. Multimodality imaging of peripheral neuropathies of the upper limb and brachial plexus. Radiographics 2010;30(5):1373-400. CrossRef

25. Gaskin CM, Helms CA. Parsonage-Turner syndrome: MR imaging findings and clinical information of 27 patients. Radiology 2006;240(2):501-7.

26. Scalf RE, Wenger DE, Frick MA, Mandrekar JN, Adkins MC. MRI findings of 26 patients with Parsonage-Turner syndrome. AJR Am J Roentgenol 2007;189(1):W39-44.

27. Pratt N. Anatomy of nerve entrapment sites in the upper quarter. J Hand Ther 2005;18(2):216-29.

28. Robinson P, White LM, Lax M, Salonen D, Bell RS. Quadrilateral space syndrome caused by glenoid labral cyst. AJR Am J Roentgenol 2000;175(4):1103-5.

29. Ludig T, Walter F, Chapuis D, Molé D, Roland J, Blum A. MR imaging evaluation of suprascapular nerve entrapment. Eur Radiol 2001;11(11):2161-9.

30. Ferdinand BD, Rosenberg ZS, Schweitzer ME, Stuchin SA, Jazrawi LM, Lenzo SR, Meislin RJ, Kiprovski K. MR imaging features of radial tunnel syndrome: initial experience. Radiology 2006;240(1):161-8.
31. Bencardino JT, Rosenberg ZS. Entrapment neuropathies of the shoulder and elbow in the athlete. Clin Sports Med 2006;25(3):465-87.

32. Bordalo-Rodrigues $M$, Rosenberg ZS. MR imaging of entrapment neuropathies at the elbow. Magn Reson Imaging Clin N Am 2004;12(2):247-63.

33. Ouellette $H$, Bredella M, Labis J, Palmer WE, Torriani M. MR imaging of the elbow in baseball pitchers. Skeletal Radiol 2008;37(2):115-21.

34. O'Hara JJ, Stone JH. Ulnar nerve compression at the elbow caused by a prominent medial head of the triceps and an anconeus epitrochlearis muscle. J Hand Surg $\mathrm{Br}$ 1996;21(1):133-5.

35. O'Driscoll SW, Horii E, Carmichael SW, Morrey BF. The cubital tunnel and ulnar neuropathy. J Bone Joint Surg $\mathrm{Br}$ 1991;73(4):613-7.

36. Husarik DB, Saupe N, Pfirrmann CW, Jost B, Hodler J, Zanetti M. Elbow nerves: MR findings in 60 asymptomatic subjects -normal anatomy, variants, and pitfalls. Radiology 2009;252(1):148-156. CrossRef

37. Grainger AJ, Campbell RS, Stothard J. Anterior interosseous nerve syndrome: appearance at MR imaging in three cases. Radiology 1998;208(2):381-4.

38. Kim S, Choi JY, Huh YM, Song HT, Lee SA, Kim SM, Suh JS. Role of magnetic resonance imaging in entrapment and compressive neuropathy -what, where, and how to see the peripheral nerves on the musculoskeletal magnetic resonance image: part 2. Upper extremity. Eur Radiol 2007;17(2):509-22.

39. Tate DE Jr. Isolated fascial compression of the recurrent motor branch of the median nerve: a case report. Hand (N Y) 2006;1(2):102-5. CrossRef

40. Harish S, Saifuddin A, Fajinmi M. Epithelioid sarcoma of the median nerve mimicking a peripheral nerve sheath tumour. Australas Radiol 2007;51(1):71-4.

41. Tagliafico A, Pugliese F, Bianchi S, Bodner G, Padua L, Rubino M, Martinoli C. High-resolution sonography of the palmar cutaneous branch of the median nerve. AJR Am J Roentgenol 2008;191(1):107-14. CrossRef

42. Lanzetta M, Foucher G. Association of Wartenberg's syndrome and De Quervain's disease: a series of 26 cases. Plast Reconstr Surg 1995;96(2):408-12. 